\title{
Indole Chloropyridinyl Ester-Derived SARS-CoV-2 3CLpro Inhibitors: Enzyme Inhibition, Antiviral Efficacy, Structure-Activity Relationship, and X-ray Structural Studies
}

\author{
Arun K. Ghosh,* Jakka Raghavaiah, Dana Shahabi, Monika Yadav, Brandon J. Anson, Emma K. Lendy,
} Shin-ichiro Hattori, Nobuyo Higashi-Kuwata, Hiroaki Mitsuya, and Andrew D. Mesecar

Cite This: https://doi.org/10.1021/acs.jmedchem.1c01214

Read Online

ABSTRACT: Here, we report the synthesis, structure-activity relationship studies, enzyme inhibition, antiviral activity, and X-ray crystallographic studies of 5-chloropyridinyl indole carboxylate derivatives as a potent class of SARS-CoV-2 chymotrypsin-like protease inhibitors. Compound 1 exhibited a SARS-CoV-2 $3 \mathrm{CLpro}$ inhibitory $\mathrm{IC}_{50}$ value of $250 \mathrm{nM}$ and an antiviral $\mathrm{EC}_{50}$ value of $2.8 \mu \mathrm{M}$ in VeroE6 cells. Remdesivir, an RNA-dependent RNA polymerase inhibitor, showed an antiviral $\mathrm{EC}_{50}$ value of $1.2 \mu \mathrm{M}$ in the same assay. Compound 1 showed comparable antiviral activity with remdesivir in immunocytochemistry assays. Compound $\mathbf{7 d}$ with an $\mathrm{N}$-allyl derivative showed the most potent enzyme inhibitory $\mathrm{IC}_{50}$ value of $73 \mathrm{nM}$. To obtain molecular insight into the binding properties of these molecules, X-ray crystal structures of compounds $\mathbf{2}, \mathbf{7 b}$, and $\mathbf{9 d - b o u n d ~ t o ~ S A R S - C o V ~ 3 C L p r o ~ w e r e ~ d e t e r m i n e d , ~ a n d ~ t h e i r ~ b i n d i n g ~ p r o p e r t i e s ~ w e r e ~ c o m p a r e d . ~}$

\section{INTRODUCTION}

The human coronavirus disease 2019 (COVID-19) is an infectious disease caused by severe acute respiratory syndrome coronavirus 2 (SARS-CoV-2), a newly discovered coronavirus. ${ }^{1,2}$ The disease first originated in Wuhan, China, and then spread rapidly around the world. The outbreak escalated into an ongoing pandemic, leading to a catastrophic public health crisis and incredible uncertainty around the globe. ${ }^{3,4}$ As of July 5, 2021, more than 185 million patients were infected with COVID-19 and there were more than 4 million deaths worldwide. ${ }^{5}$ Currently, there is no specific efficacious drug treatment available for COVID-19, except remdesivir, which has been granted an emergency-use authorization. ${ }^{6,7}$ Research suggests that remdesivir may provide only modest benefit to patients with COVID-19 infection. ${ }^{8,9}$ While current large-scale vaccination efforts are showing benefits, the hope that COVID19 will be under control with "herd immunity" is quite uncertain. ${ }^{10,11}$ Furthermore, there is no conclusive evidence yet that COVID-19-convalescent people with SARS-CoV-2 antibodies are immune to reinfection. ${ }^{12,13}$ Therefore, it is an urgent priority to develop potent antiviral drugs that can effectively mitigate the lethal consequences of cytokine storm in COVID-19 patients.

The SARS-CoV-2 RNA genome sequence provided an excellent starting point for drug discovery and development of effective therapeutics against COVID-19. ${ }^{14,15}$ SARS-CoV-2 belongs to a family of beta coronaviruses, including SARS-CoV and Middle East respiratory syndrome coronavirus (MERSCoV), responsible for outbreaks of SARS and MERS in 2003 and 2012, respectively. ${ }^{16,17}$ The SARS-CoV-2 genome has an overall $80 \%$ nucleotide identity with SARS-CoV, and the main proteases of these viruses have more than $90 \%$ amino acid sequence identity. ${ }^{18,19}$ Earlier medicinal chemistry efforts for the control of SARS-CoV and MERS-CoV infections have laid important early groundwork for design, synthesis, and development of small-molecule lead inhibitors of the main proteases, mainly chymotrypsin-like protease (3CLpro and Mpro) and papain-like protease (PLpro). ${ }^{20-22}$ Both of these proteases are essential for viral replication and transcription of the genome, and they are very important targets for developing antiviral therapeutics against COVID-19. The structure, activity, and active sites of these proteases have been elucidated. $^{23}$ Early and recent drug development efforts including development of covalent and noncovalent inhibitors of these proteases have been recently reviewed. ${ }^{23,24}$ Among small-molecule drug development targets for treatment of COVID-19, there is considerable interest in the activity of SARS-CoV-2 3CLpro inhibitors. ${ }^{23-25}$ Recently, we have reported that a combination of a peptidomimetic SARSCoV-2 3CLpro inhibitor with remdesivir exhibits synergism against SARS-CoV-2. ${ }^{26}$ Oral or intraperitoneal administration of dipeptidyl 3CLpro inhibitors has been shown to reduce lung

Received: July 7, 2021 
viral loads and lung lesions in a transgenic mouse model of SARS-CoV-2 infection. ${ }^{27}$ A small-molecule inhibitor of SARSCoV-2 3CLpro has been reported as entering into phase I clinical trials. ${ }^{28}$

In our continuing efforts toward the treatment of SARS-CoV and SARS-CoV-2, we have developed a variety of potent peptidomimetic and nonpeptide-derived small-molecule protease inhibitors. ${ }^{26,29-34}$ The SARS-CoV and SARS-CoV-2 3CLpro active sites possess a catalytic dyad where Cys 145 acts as a nucleophile and His41 acts as the general acid-base. We and others have reported a series of covalent 3CLpro inhibitors against SARS-CoV and SARS-CoV-2 where the mode of inhibition involves acylation of the active site cysteine, forming a covalent bond with the inhibitor. ${ }^{35-38}$ In particular, ester derivatives of 5-chloropyridin-3-ol with various indole carboxylic acids (compounds $\mathbf{1}$ and 2, Figure 1) displayed
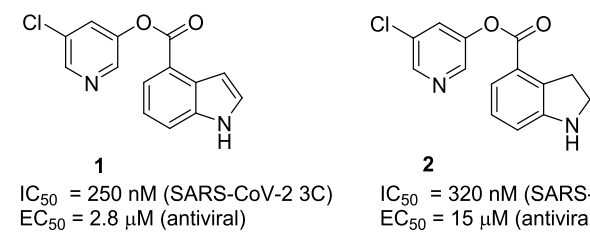

$\mathrm{IC}_{50}=320 \mathrm{nM}$ (SARS-CoV-2 3C) $\mathrm{EC}_{50}=2.8 \mu \mathrm{M}$ (antivira) $\mathrm{EC}_{50}=15 \mu \mathrm{M}$ (antiviral)
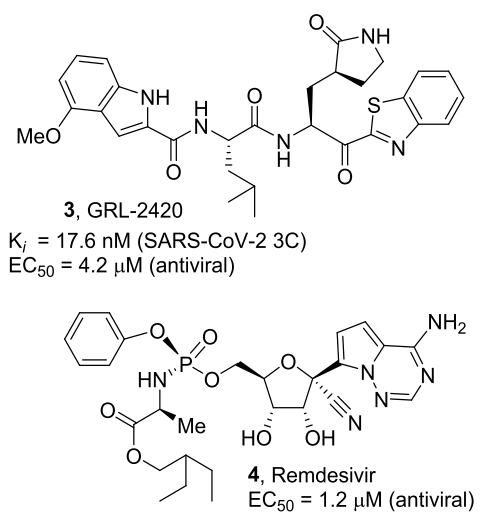

Figure 1. Structures of SARS-CoV-2 3CLpro inhibitors 1-3 and RdRp inhibitor, remdesivir, 4.

potent 3CLpro inhibitory activity and exerted potent antiviral activity against SARS-CoV and SARS-CoV-2 in VeroE6 cellbased assays. $^{26,29}$ The keto-benzothiazole derivative 3 exhibited potent enzyme inhibitory and antiviral activities. ${ }^{26}$ Remdesivir (4), an RNA-dependent RNA polymerase inhibitor, displayed comparable antiviral activity to inhibitors $\mathbf{1}$ and 2. ${ }^{6,26}$ We have further investigated various indole carboxylic acid-derived inhibitors. It appears that the position of the carboxylic acids and substituents on the indole ring are important to SARS-CoV-2 3CLpro inhibitory potency and antiviral activity. Presumably, the indole carboxylate scaffold plays a key role in binding to the 3CLpro active site. For an understanding of active site interactions, we determined X-ray crystal structures of inhibitor-bound SARS-CoV-2 and SARSCoV-1 3CLpro. Herein, we report the design, synthesis, structure-activity relationship studies, enzyme inhibition studies, antiviral activity, and X-ray structural studies of 5chloropyridin-3-yl ester-derived SARS-CoV-2 3CLpro inhibitors.

\section{RESULTS AND DISCUSSION}

The general synthesis of various 5-chloropyridin-3-yl esterderived SARS-CoV-2 3CLpro inhibitors is shown in Scheme 1.

Scheme 1. Synthesis of Inhibitors $7 a-m$ and $9 a-f^{a}$<smiles>[R]n1ccc2cc(C(=O)O)ccc21</smiles>

5a: $\mathrm{R}=\mathrm{H}$

5b: $\mathrm{R}=3-\mathrm{NO}_{2} \mathrm{PhSO}_{2}$<smiles>[R3]c1cc2[nH]cc([R])c2c(C(=O)O)c1[R]</smiles>

5f: $R_{1}=M e, R_{2}=R_{3}=H$

5g: $R_{2}=M e, R_{1}=R_{3}=H$

5h: $R_{3}=M e, R_{1}=R_{2}=H$

5i: $R_{3}=F, R_{1}=R_{2}=H$

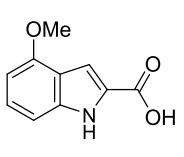

$5 c$

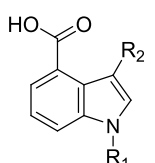

5d: $R_{1}=$ allyl, $R_{2}=H$

5e: $R_{1}=R_{2}=$ allyl
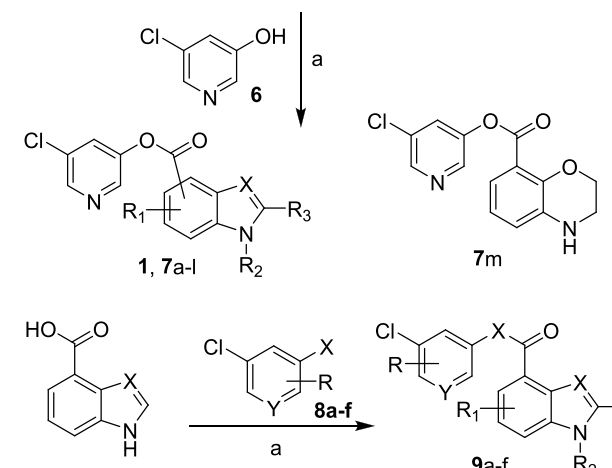

5n: $\mathrm{X}=\mathrm{CH}$
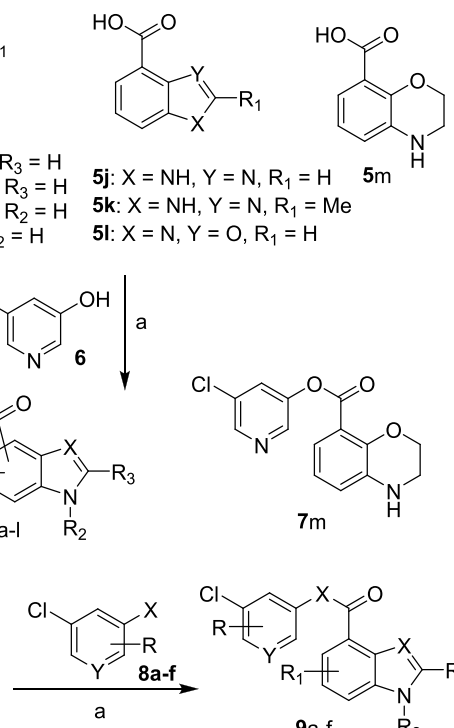

$\mathrm{X}=\mathrm{NH}, \mathrm{Y}=\mathrm{N}, \mathrm{R}_{1}=\mathrm{H} \quad \mathbf{5 m}$

5k: $X=N H, Y=N, R_{1}=M$

$X=N, Y=O, R_{1}=H$

5j: $X=N$

${ }^{a}$ Reagents and chemicals: (a) EDC, DMAP, $\mathrm{CH}_{2} \mathrm{Cl}_{2}, 23{ }^{\circ} \mathrm{C}(60-$ $80 \%)$.

Inhibitors $\mathbf{1}-\mathbf{2}$ and $\mathbf{7} \mathbf{a}-\mathbf{m}$ were synthesized by esterification of respective carboxylic acids. The majority of the requisite carboxylic acids are commercially available and a few modified derivatives were readily prepared. Carboxylic acids $\mathbf{5 a}-\mathbf{1}$ and 5chloro-3-pyridinol were esterified using 1-ethyl-3-(3dimethylaminopropyl)carbodiimide (EDC) in the presence of dimethylaminopyridine (DMAP) in $\mathrm{CH}_{2} \mathrm{Cl}_{2}$ at $23{ }^{\circ} \mathrm{C}$ for 12 h. The resulting esters were purified by silica gel chromatography to provide air-stable ester derivatives in good to excellent yields (40-90\%). Similarly, commercially available 3,4dihydro-2H-benzo[b][1,4] oxazine-8-carboxylic acid $5 \mathrm{~m}$ was converted to ester derivative $7 \mathbf{m}$. The structures of the various 5-chloropyridin-3-yl esters are shown in Table 1 . The synthesis of active ester derivatives $\mathbf{9 a}-\mathbf{f}$ containing methyl-substituted 5-chloropyridin-3-ol was achieved by a reaction of indole-4carboxylic acids $\mathbf{5 j}$ and $\mathbf{5 n}$ with the respective commercially available substituted pyridinol derivatives $8 \mathbf{a}-\mathbf{f}$ with EDC in the presence of DMAP under similar conditions as stated above. The synthesis of ester derivatives $7 \mathbf{a}, 7 \mathbf{b}, 7 \mathbf{d}$, and $7 \mathbf{e}$ is shown in Scheme 2. Commercially available methyl-1H-indole5-carboxylate 10 was saponified with $1 \mathrm{M} \mathrm{LiOH}$ in an aqueous tetrahydrofuran (THF) solution at $23{ }^{\circ} \mathrm{C}$ for $30 \mathrm{~min}$. The resulting acid was esterified with 5-chloro-3-pyridinol 6 to provide the ester derivative $7 \mathbf{a}$. For the synthesis of ester $7 \mathbf{b}$, methyl ester 10 was treated with $\mathrm{NaH}$ in THF at $23^{\circ} \mathrm{C}$ for $1 \mathrm{~h}$. After this period, 3-nitrophenylsulfonyl chloride was added and the resulting mixture was stirred for $23 \mathrm{~h}$ to provide the 
Table 1. Structures and Activity of 3-Chloropyridinyl EsterDerived SARS-CoV-2 3CLpro Inhibitors ${ }^{a}$

\begin{tabular}{|c|c|c|c|}
\hline entry & $\begin{array}{l}\text { entry compound } \\
\text { structure }\end{array}$ & $\begin{array}{c}\text { SARS-CoV-2 } \\
3 C L p r o \\
I_{50}(\mu \mathrm{M})\end{array}$ & $\begin{array}{l}\text { SARS-CoV-2 } \\
E C_{50}(\mu \mathrm{M})^{\mathrm{a}}\end{array}$ \\
\hline 1 & & 0.25 & 2.8 \\
\hline 2 & & 0.32 & 15 \\
\hline 3 & 7a & 0.31 & 43.7 \\
\hline 4 & $7 b$ & 0.12 & 69.8 \\
\hline 5 & 7c & 0.90 & 8.1 \\
\hline 6 & $d \mathrm{~d}$ & 0.073 & 15 \\
\hline 7 & & 0.38 & 11.5 \\
\hline 8 & & 0.47 & 56.7 \\
\hline 9 & & 10.3 & $>100$ \\
\hline 10 & 7h & 0.59 & 3.1 \\
\hline 11 & & 0.87 & 14 \\
\hline 12 & & 0.34 & $>100$ \\
\hline 13 & & 0.49 & 57.1 \\
\hline 14 & & 1.19 & $>100$ \\
\hline 15 & & 0.42 & $>100$ \\
\hline
\end{tabular}

${ }^{a}$ Compounds 3 and 4 exhibited antiviral $\mathrm{EC}_{50}$ values of 3.4 and 3.2 $\mu \mathrm{M}$, respectively.
Scheme 2. Synthesis of Inhibitors $7 a, 7 b, 7 d$, and $7 e^{a}$<smiles>COC(=O)c1ccc2[nH]c3cc(CC4CCCCC4)ccc3c2c1</smiles><smiles>COC(=O)c1ccc2c(ccn2S(=O)(=O)c2cccc([N+](=O)[O-])c2)c1</smiles><smiles>C=CCn1ccc2c(C(=O)OC)cccc21</smiles><smiles>C=CCc1cn(CC=C)c2cccc(C(=O)Oc3cncc(Cl)c3)c12</smiles>

${ }^{a}$ Reagents and chemicals: (a) LiOH, THF- $\mathrm{H}_{2} \mathrm{O}, 23{ }^{\circ} \mathrm{C}, 30 \mathrm{~min}$; (b) 5-chloro-3-pyridinol 6, EDC, DMAP, $\mathrm{CH}_{2} \mathrm{Cl}_{2}, 23{ }^{\circ} \mathrm{C}, 12 \mathrm{~h}$; (c) $\mathrm{NaH}$, $m-\mathrm{NO}_{2}-\mathrm{PhSO}_{2} \mathrm{Cl}$, THF, $23{ }^{\circ} \mathrm{C}, 24 \mathrm{~h}$; (d) NaH, allylbromide, THF, 23 ${ }^{\circ} \mathrm{C}, 12 \mathrm{~h}$; and (e) $1 \mathrm{~N} \mathrm{NaOH}, \mathrm{EtOH}-\mathrm{H}_{2} \mathrm{O}, 85{ }^{\circ} \mathrm{C}, 3 \mathrm{~h}$.

sulfonamide derivative $11 .^{39}$ Saponification of ester 11 with aqueous $\mathrm{LiOH}$ provided the corresponding carboxylic acid, which was converted to 3-chloro-pyridinyl ester $7 \mathbf{b}$ as described above.

For the synthesis of active esters $7 \mathbf{d}$ and $7 \mathbf{e}$, commercially available methyl- $1 \mathrm{H}$-indole-4-carboxylate 12 was treated with $\mathrm{NaH}$ in THF from 0 to $23{ }^{\circ} \mathrm{C}$ for $1 \mathrm{~h}$. Then, allyl bromide was added and the resulting reaction was stirred for $12 \mathrm{~h}$ at $23{ }^{\circ} \mathrm{C}$ to provide the monoallyl derivative $\mathbf{1 3}$ and the diallyl derivative 14 as a 7.5:1 mixture. ${ }^{40}$ These isomers were separated by silica gel chromatography. The respective ester was saponified with 1 $\mathrm{N} \mathrm{NaOH}$ in EtOH at $85{ }^{\circ} \mathrm{C}$ for $3 \mathrm{~h}$ to provide the corresponding acid. The resulting carboxylic acid derivatives were esterified as described above to provide esters $7 \mathbf{d}$ and $7 \mathbf{e}$ in good yields.

Our SARS-CoV-2 3CLpro inhibition assays of active ester derivatives were carried out using the authentic SARS-CoV-2 3CLpro enzyme that would be generated during viral replication, that is, no additional amino acids on the $N$ - or $\mathrm{C}$-termini. The details of the expression and purification of the fully active SARS-CoV-2 3CLpro construct have been published recently. ${ }^{29,41}$ The inhibitory activity ( $\mathrm{IC}_{50}$ values) of compounds was assessed using a continuous fluorescence assay and the FRET-based substrate UIVT3 (HiLyte Fluor 
488-ESATLQSGLRKAK-QXL520- $\mathrm{NH}_{2}$ ) (AnaSpec, Fremont, CA) as described previously. ${ }^{31,42}$

We resynthesized and assessed the activity of 4-chloropyridinyl indole-4-carboxylate $\mathbf{1}$, which was previously identified by us as a potent and irreversible inhibitor of SARS-CoV ( $\mathrm{IC}_{50}$ $=30 \mathrm{nM}$; antiviral $\mathrm{EC}_{50}=6.9 \mu \mathrm{M}$ in VeroE6 cells). ${ }^{35}$ The structure and activity of various new compounds are shown in Tables 1 and 2. Compound 1 exhibited a SARS-CoV-2 3CLpro

Table 2. Structures and Activity of Substituted Active EsterDerived SARS-CoV-2 3CLpro Inhibitors ${ }^{a}$

(10)

${ }^{a}$ Compounds 3 and 4 exhibited antiviral $\mathrm{EC}_{50}$ values of 3.4 and 3.2 $\mu \mathrm{M}$, respectively.

enzyme $\mathrm{IC}_{50}$ value of $250 \mathrm{nM}$. Compound 1 also displayed potent antiviral activity, which was assessed using the quantitative VeroE6 cell-based assay with RNA-quantitative polymerase chain reaction ( $\mathrm{qPCR}$ ). The details of the assay have been published recently. ${ }^{29}$

Compound 1 displayed an $\mathrm{EC}_{50}$ value of $2.8 \mu \mathrm{M}$. The high ratio of antiviral $\mathrm{EC}_{50}$ and enzyme $\mathrm{IC}_{50}$ may be due to the expression of the efflux transporter P-glycoprotein in VeroE6 cells. Such discrepancies have been documented recently. ${ }^{43,44}$ This compound exhibited cytotoxicity $\left(\mathrm{CC}_{50}\right)$ value $>100 \mu \mathrm{M}$. Remdesivir (4), a nucleotide derivative that reportedly blocks the infectivity of SARS-CoV-2 by inhibiting the viral RNAdependent RNA polymerase (RdRp), was also assayed in the same assay to compare the antiviral activity. Remdesivir exhibited an antiviral $\mathrm{EC}_{50}$ value of $1.2 \mu \mathrm{M}$. Furthermore, we investigated the antiviral activity of compound $\mathbf{1}$ and remdesivir at 1,10 , and $100 \mu \mathrm{M}$ to assess if these compounds exert antiviral activity without significant cytostatic or cytotoxic effects. As reported recently, both compounds completely blocked the infectivity and cytopathic effect of SARS-CoV$2^{\text {WK-521 }}$ in VeroE6 cells. ${ }^{26,29}$

We then investigated the effect of various substitutions on the indole ring as well as on the chloropyridine ring of the ester. As can be seen, the indoline derivative 2 showed only a slight reduction in inhibitory potency against the SARS-CoV-2 3CLpro enzyme $\left(\mathrm{IC}_{50}=320 \mathrm{nM}\right)$ compared to indole derivative 1. It displayed a SARS-CoV 3CLpro inhibitory $\mathrm{IC}_{50}$ value of $190 \mathrm{nM}$. Also, it showed a fivefold reduction in the antiviral activity $\left(\mathrm{EC}_{50}=15 \mu \mathrm{M}\right)$ compared to 1 . Substitution of chloropyridinyl ester at the 5-position of the indole ring provided derivative $7 \mathbf{a}$ (entry 3 ), which displayed a comparable $\mathrm{IC}_{50}$ value to compounds 1 and 2 but it was significantly less potent than 1 or 2 against the virus $\left(\mathrm{EC}_{50}=\right.$ 43.7 $\mu \mathrm{M}$ ). Compound 7a exhibited comparable SARS-CoV 3CLpro activity $\left(\mathrm{IC}_{50}=310 \mathrm{nM}\right)$. Incorporation of a 3-nitro sulfonamide functionality on the indole nitrogen provided compound $7 \mathbf{b}$. This compound showed improvement in the SARS-CoV-2 3CLpro inhibitory activity (entry 4). Substitution of chloropyridinyl ester at the 4-position of the indole ring resulted in compound 7c. Interestingly, it showed a reduction in the enzyme inhibitory activity, but showed an antiviral $\mathrm{EC}_{50}$ value of $8 \mu \mathrm{M}$ (entry 5). Both compounds $7 \mathbf{b}$ and $7 \mathbf{c}$ were less potent against SARS-CoV 3CLpro ( $\mathrm{IC}_{50}$ values of 120 and 900 $\mathrm{nM}$, respectively). We then examined the structure-activity relationships associated with compound 1. Incorporation of an $N$-allyl substituent resulted in compound $\mathbf{7 d}$, which exhibited over fivefold improvement in the inhibitory potency over $\mathbf{1}$. However, compound $\mathbf{7 d}$ displayed an antiviral $\mathrm{EC}_{50}$ value of 15 $\mu \mathrm{M}$, a nearly fivefold reduction over compound 1 (entry 6). The bis-allyl derivative $7 \mathrm{e}$ showed a fivefold reduction in the enzyme inhibitory activity but showed a slight improvement in the antiviral activity over $\mathbf{7 d}$ (entry 7 ).

We further investigated the effect of methyl substitution on the indole ring in an attempt to facilitate the bioactive conformation of the pyridyl ester. Accordingly, incorporation of a methyl group on the indole at positions 3,5 , and 6 resulted in compounds $7 \mathbf{f}, 7 \mathrm{~g}$, and $7 \mathrm{~h}$, respectively (entries 810). The inhibitor $7 \mathrm{~g}$ with 5 -methyl indole resulted in significant loss of the SARS-CoV-2 3CLpro inhibitory activity, and this compound did not exhibit any appreciable antiviral activity $\left(\mathrm{EC}_{50}>100 \mu \mathrm{M}\right)$. Compound 7 h containing 6-methyl indole showed a slight reduction in the enzyme inhibitory activity; however, this compound maintained its potent antiviral activity $\left(\mathrm{EC}_{50}=3.1 \mu \mathrm{M}\right)$, comparable to inhibitor 1 (entry 10). The incorporation of the methyl group at position 5 on the indole ring most likely disrupted or reduced the available angle of attack of the Cys145 nucleophile on the ester group, thereby reducing its potency. ${ }^{45}$

Incorporation of fluorine at position 6 provided inhibitor $7 \mathbf{i}$ with loss of enzyme inhibitory and antiviral activities. We then investigated the effect of incorporation of heteroatoms and the importance of the 5-membered pyrrole ring on indole. Compound $7 \mathbf{j}$ with a benzoimidazole aromatic heterocyclic group showed an enzyme $\mathrm{IC}_{50}$ value of $340 \mathrm{nM}$ but no appreciable antiviral activity (entry 12). Further incorporation of a 2-methyl group on compound $7 \mathbf{j}$ provided derivative $7 \mathbf{k}$, 
which displayed an enzyme $\mathrm{IC}_{50}$ value of $490 \mathrm{nM}$ and an antiviral $\mathrm{EC}_{50}$ value of $57 \mu \mathrm{M}$ (entry 13). Compound 71 with a benzooxazole heterocyclic group showed a reduction in potency (entry 14). Compound $7 \mathbf{m}$ with a dihydrobenzooxazine heterocycle exhibited a good enzyme inhibitory activity; however, the antiviral activity was poor $\left(\mathrm{EC}_{50}>100 \mu \mathrm{M}\right)$.

We then examined the importance of 5-chloropyridinyl ester in compound 1. The structure and activity of various derivatives are shown in Table 2. As shown, we examined the importance of an ester over its amide derivative. The 5chloropyridyl indole carboxamide derivative 9a did not exhibit any appreciable enzyme inhibitory or antiviral activity. We also prepared a 3-chlorophenyl indole derivative $\mathbf{9 b}$, but this compound did not exhibit any activity either, showing the importance of the pyridinyl ester functionality (entries 1 and 2 ). We then incorporated a methyl group on the pyridine ring to examine the effect of the alkyl group on potency. Substitution of 2-methyl, 4-methyl, or 6-methyl groups resulted in compounds $9 \mathrm{c}, \mathbf{9 d}$, and $9 \mathrm{e}$. Interestingly, 2-methyl substitution provided inhibitor $9 \mathrm{c}$ with no appreciable activity (entry 3). Substitution at 4 and 6 positions also resulted in significant reductions in potency (entries 4 and 5). The benzimidazole derivative $9 \mathrm{f}$ with 6-methyl-5-chloropyridynyl ester showed a significant reduction in the protease inhibitory activity compared to its desmethyl derivative $7 \mathbf{j}$ in Table 1 (entry 6).

As mentioned earlier, our antiviral activity assays were performed using the quantitative RNA-qPCR assay in VeroE6 cells. $^{26,29}$ In the present study, in order to confirm and corroborate the anti-SARS-CoV-2 activity $\left(\mathrm{EC}_{50}, \mu \mathrm{M}\right)$ shown in Tables 1 and 2, which often fails to differentiate the actual antiviral activity from the misleading and distractive reduction in RNA copy numbers caused by the cytostatic effect or cytotoxicity of test compounds, we have employed immunocytochemistry, which allows us to examine the antiviral activity of test compounds at the cellular level. In immunocytochemistry, the IgG fraction isolated from a COVID-19-convalescent patient, who had high-titer SARS-CoV-2-binding $\mathrm{IgG}^{46}$ and a green fluorescence-conjugated goat polyclonal antihuman IgGAlexa Fluor $488 \mathrm{Fab}$ fragment were employed as the primary and secondary antibodies, respectively, together with Texas Red-X dye-conjugated Phalloidin and DAPI for visualization of filamentous actin (F-actin) and cell nuclei, respectively. ${ }^{26,29}$ As shown in Figure 2, when VeroE6 cells were cultured alone, robust cellular cytoskeleton F-actin was observed as mesh-like structures in red and a number of nuclei (in blue) were identified, signifying that these VeroE6 cells were healthy and replicating (top left in Figure 2). However, when VeroE6 cells were exposed to SARS-CoV-2 ${ }^{\text {WK-521 }}$ and cultured in the absence of a test compound, the F-actin structure was lost and a number of cells had been infected and destroyed by the virus and stained in green (top right in Figure 2). In contrast, when the SARS-CoV-2 ${ }^{\text {WK-521 }}$-exposed VeroE6 cells were cultured in the presence of $10 \mu \mathrm{M}$ compounds 1 and 2, there was a significant reduction in the number of SARS-CoV-2 ${ }^{\text {WK-521 }}$. infected cells, and there were essentially no infected cells when the cells were cultured in the presence of $100 \mu \mathrm{M}$ of each compound. Remdesivir, the only Food and Drug Administration (FDA)-approved antiviral therapeutic drug as of writing, also significantly reduced the number of infected cells at 10 and $100 \mu \mathrm{M}$, while there was viral breakthrough in the culture with $10 \mu \mathrm{M}$. Of particular note, among the various active esters examined, compound 1 exerted potent antiviral
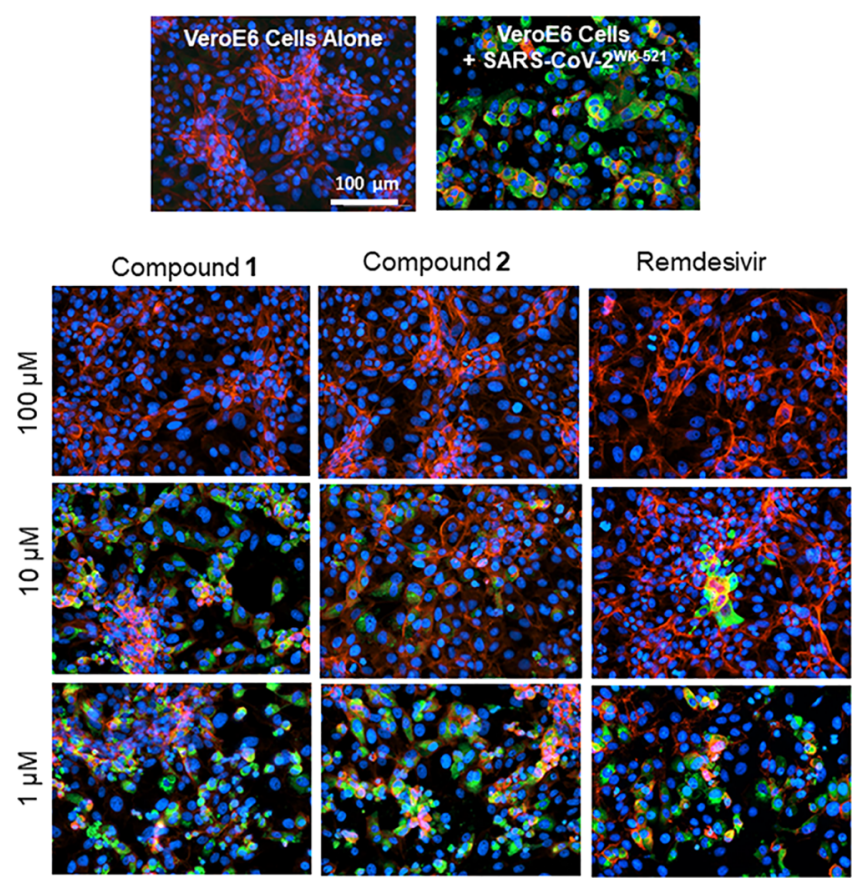

Figure 2. Inhibitors 1 and 2 and remdesivir potently blocked the infectivity and cytopathic effect of SARS-CoV-2 $2^{\text {WK-521 }}$ in VeroE6 cells. VeroE6 cells were exposed to SARS-CoV-2 $2^{\text {WK-521 }}$ at an MOI of 0.05 and cultured in the presence or absence of test compounds. After 3 days, the cells were fixed with $4 \%$ paraformaldehyde, and immunocytochemistry was conducted using the $\operatorname{IgG}$ fraction from serum of a COVID-19-convalescent patient, who had high-titer SARS$\mathrm{CoV}$-2-binding $\mathrm{IgG}^{29}$ and a green fluorescence-conjugated goat polyclonal antihuman IgG-Alexa Fluor $488 \mathrm{Fab}$ fragment as the primary and secondary antibodies, respectively. SARS-CoV-2 antigens, F-actin, and nuclei are shown in green, red, and blue, respectively.

activity $\left(\mathrm{EC}_{50}=2.8 \mu \mathrm{M}\right)$ and significantly reduced the infectivity, replication, and cytopathic effect of SARS-CoV-2 without significant toxicity.

The mechanism of inhibition of SARS protease has been studied by us and others previously. ${ }^{35,36,47}$ Indole chloropyridinyl ester 1 covalently modifies SARS-CoV-2 3CLpro forming a thioester bond with the catalytic Cys 145 and the indole carbonyl group. The presence of the covalent bond was verified by electrospray ionization and quadruple time-of-flight mass spectrometry (ESI-QTOF/MS). The proposed inhibition of SARS-CoV-2 3CLpro is shown in Figure 3. As shown, the catalytic dyad of 3CLpro, His41, and Cys145 are involved in the nucleophilic attack on the 5-chloropyridinyl ester of inhibitor 1 to form a tetrahedral intermediate 13, which then expels the chloropyridinyl group and forms a covalent bond with Cys145 of SARS-CoV-2 3CLpro. In essence, the 5chloropyridinyl indole ester acylated Cys 145 in the active site. In mouse hepatitis virus coronavirus 3CLpro, this thioester bond can be slowly hydrolyzed by bulk water, releasing an active enzyme, and the rates of release are affected by drugresistant mutants. ${ }^{48}$

To obtain further molecular insight into the inhibition of SARS-CoV-2 3CLpro by the active esters, we determined the $\mathrm{X}$-ray structures of SARS-CoV-2 3CLpro bound with inhibitors 2 and $9 \mathrm{~d}$ at $1.65 \AA$ A resolution. Also, we determined the X-ray structure of SARS-CoV 3CLpro in complex with inhibitor $7 \mathbf{b}$ at $1.63 \AA$ resolution. The X-ray data collection and refinement 


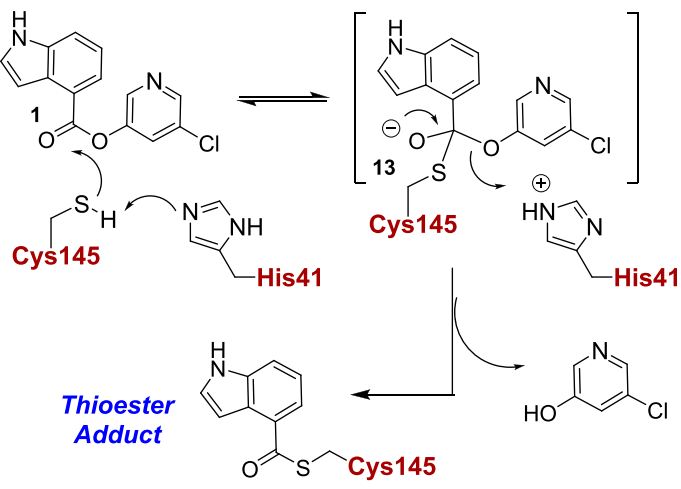

Figure 3. Mechanism of inhibition of SARS-CoV-2 3CLpro by compound 1. Structure 13 represents the presumed tetrahedral intermediate formed prior to the thioester intermediate.

statistics for all three complexes are summarized in Table S1 (please see Supporting Information). The electron density maps for the reaction product of inhibitor 2 and SARS-CoV-2 3CLpro and inhibitor 9d and SARS-CoV-2 3CLpro are shown in Figures 4 and 5, respectively. As can be seen, Cys145 is

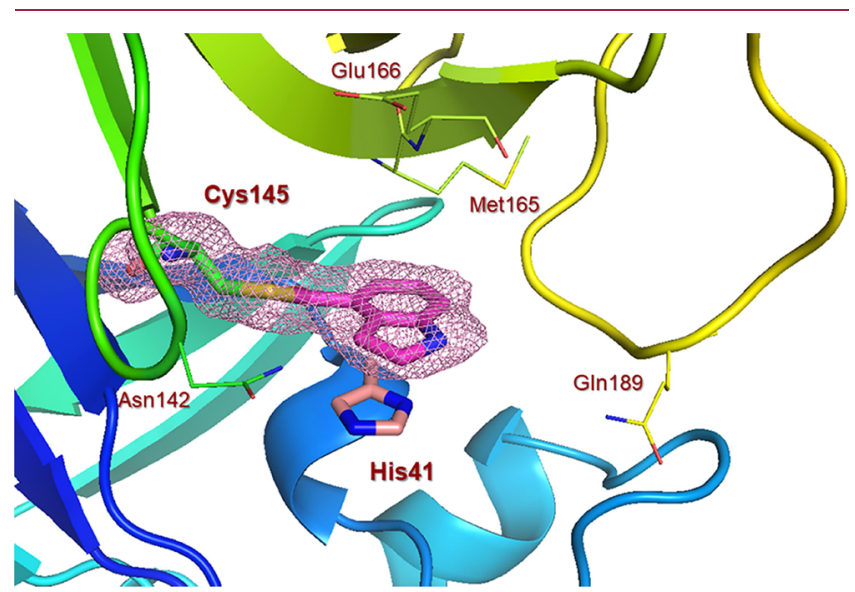

Figure 4. X-ray structure of SARS-CoV-2 3CLpro bound with compound 2 at $1.65 \AA$. Polder electron density omit maps $\left(\mathrm{mF}_{\mathrm{obs}}-\right.$ $\left.\mathrm{DF}_{\text {model }}\right)$ surrounding compound $\mathbf{2}$ and Cys145. Electron density is contoured at $3.5 \sigma .(+)$ density is colored pink and (-) density is colored green. Final $R_{\text {work }}=16.7 \%$ and $R_{\text {free }}=18.9 \%$. The thioester bond between Cys145 and compound 2 is clearly visible (PDB code:7RBZ).

covalently attached to the indoline carbonyl group of $\mathbf{2}$ and the indole carbonyl group of $9 \mathrm{~d}$ in the $\mathrm{S} 1$ pocket. It is important to note that after $\mathrm{X}$-ray structural refinement that included occupancy refinement of the ligand and His41, the thioester intermediate of compound 9d was bound at $80 \%$ occupancy along with His41 in one conformation (inhibitor bound) and at about $20 \%$ occupancy in another conformation, which represents the unbound structure. This is important because His41 needs to rotate out of the way to form an interaction with the indole group. Also important is that in this conformation, the carbonyl group is more protected from the solvent, keeping it stable from hydrolysis, and this is observable in the maps. The indole ring forms $\pi-\pi$ stacking with the shifted imidazole ring of His41 in both structures. There is approximately a distance of $3.5 \AA$ Aetween the His 41 imidazole ring and the phenyl ring of structure 2 and indole ring of structure 9d. Other key residues such as Asn142, Met165,

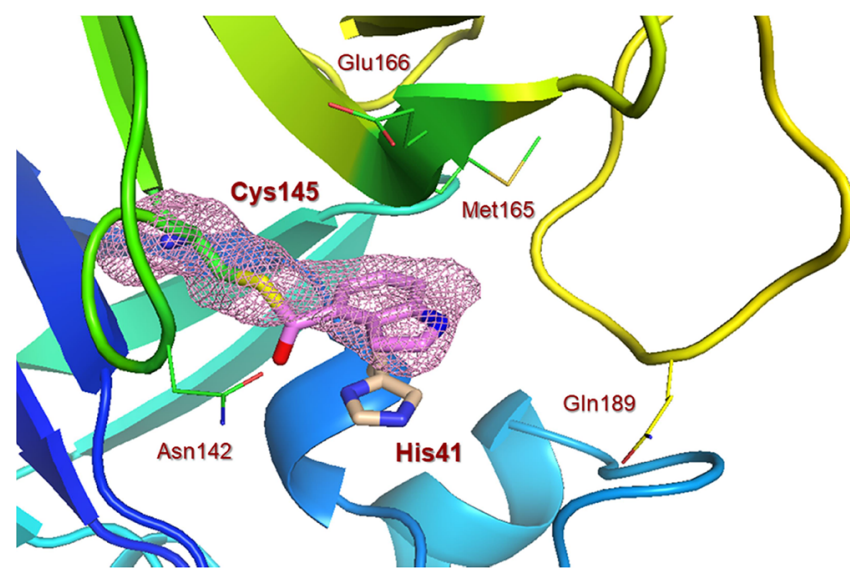

Figure 5. X-ray structure of SARS-CoV-2 3CLpro bound with compound 9d at $1.65 \AA$. Polder electron density omit maps $\left(\mathrm{mF}_{\mathrm{obs}}-\right.$ $\left.\mathrm{DF}_{\text {model }}\right)$ surrounding $\mathbf{9 d}$ and Cys145. Electron density is contoured at $3.5 \sigma .(+)$ density is colored pink and $(-)$ density is colored green but is not visible. Final $R_{\text {work }}=12.6 \%$ and $R_{\text {free }}=17.4 \%$. The thioester bond between Cys145 and 9d is clearly visible (PDB code:7RC0).

Glu166, and Gln189 are within the hydrophobic pocket surrounding these rings in both structures.

We have also determined the X-ray structure of SARS-CoV 3CLpro bound with inhibitor $7 \mathrm{~b}$ at $1.63 \AA$ resolution. The electron density map for the reaction product of inhibitor $7 \mathbf{b}$ and SARS-CoV 3CLpro is shown in Figure 6. The structure is

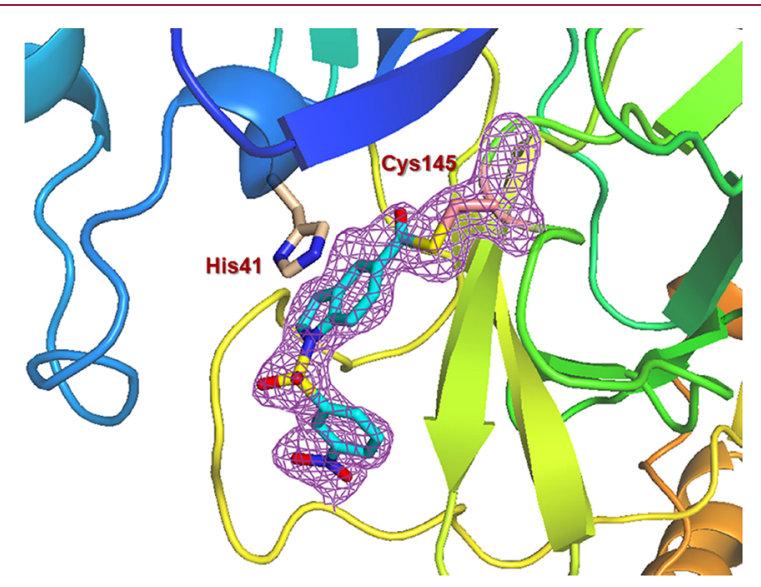

Figure 6. X-ray structure of SARS-CoV 3CLpro bound with compound $7 \mathbf{b}$ at $1.63 \AA$. Polder electron density omit maps $\left(\mathrm{mF}_{\mathrm{obs}}\right.$ $\left.-\mathrm{DF}_{\text {model }}\right)$ surrounding $7 \mathbf{b}$ and Cys 145 . Electron density is contoured at $3.5 \sigma .(+)$ density is colored violet and $(-)$ density is colored green. Final $R_{\text {work }}=19.1 \%$ and $R_{\text {free }}=22.2 \%$. The thioester bond between Cys 145 and $7 \mathbf{b}$ is clearly visible (PDB code:7RC1).

very similar to the compound 9d-bound SARS-CoV-2 3CLpro structure. The indole ring of $7 \mathbf{b}$ also forms $\pi-\pi$ stacking with the shifted imidazole ring of His41, and the distance between the His41 imidazole ring and indole ring is about $3.5 \AA$. We compared the interactions of $7 \mathbf{b}$-bound SARS-CoV 3CLpro with the compound 9d-bound SARS-CoV-2 3CLpro structure. The superimposed structures are shown in Figure 7. As can be seen, the inhibitors overlapped well. 3-Nitrobenzenesulfonamide of compound $7 \mathbf{b}$ was positioned between Gln189 and Gln192 after reaction with cysteine. The structures of the proteins SARS-CoV 3CLpro and SARS-CoV-2 3CLpro have 


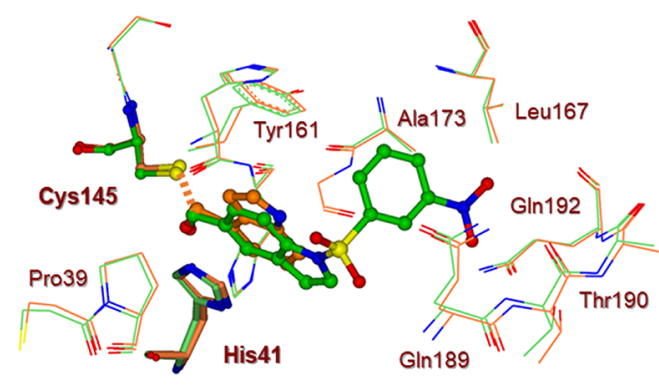

Figure 7. Superposition of SARS-CoV-2 3CLpro bound to compound 9d (orange carbon) and SARS-CoV 3CLpro bound to compound $7 \mathbf{b}$ (green carbon).

excellent overlap in many areas, particularly in the active sites of these enzymes.

\section{CONCLUSIONS}

In summary, we have designed, synthesized, and evaluated a series of potent indole 5-chloropyridinyl ester-derived SARSCoV-2 3CLpro inhibitors for the treatment of COVID-19. A number of compounds exhibited low nanomolar 3CLpro inhibitory activity. The mode of inhibition involves nucleophilic attack of catalytic Cys145 on the inhibitor's ester carbonyl group and formation of a covalent bond between Cys145 and the carbonyl group of the active ester. Our structure-activity relationship studies show that the position of the carboxylic acid on the indole ring is important for activity. A number of compounds show potent antiviral activity in VeroE6 cell-based assays with RNA-qPCR and immunocytochemistry assays. In particular, compounds $\mathbf{1}$ and $\mathbf{7 h}$ exhibited potent antiviral activity $\left(\mathrm{EC}_{50} \sim 3 \mu \mathrm{M}\right)$ comparable to compound $\mathbf{4}$ and the FDA-approved therapeutic drug, remdesivir. Furthermore, we demonstrate that the antiviral activity of compounds is not because of misleading cytostatic effects or cytotoxic effects but due to an apparent destructive "antiviral effect." We determined high-resolution X-ray structures of compounds bound to SARS-CoV 3CLpro and SARS-CoV-2 3CLpro enzymes. The structures revealed that catalytic Cys145 formed a covalent bond with the indole carbonyl group. Furthermore, the indole rings of inhibitors formed $\pi-\pi$ stacking interactions with the imidazole ring of His41, a residue that must move substantially before, during, and after reaction with the inhibitors. The present study provided a number of lead compounds with potent antiviral activities. Our X-ray structural studies offer important molecular insight into the active site interactions of these small molecules for further improvement of molecular features and activity. Further design and optimization are in progress in our laboratories.

\section{EXPERIMENTAL SECTION}

General Methods. All reactions were carried out under an argon atmosphere in either flame- or oven-dried $\left(120^{\circ} \mathrm{C}\right)$ glassware. All reagents and chemicals were purchased from commercial suppliers and used without further purification unless otherwise noted. Anhydrous solvents were obtained as follows: dichloromethane from calcium hydride, diethyl ether and tetrahydrofuran from $\mathrm{Na}$ / benzophenone, and methanol and ethanol from activated magnesium under argon. All purification procedures were carried out with reagent-grade solvents (purchased from VWR) in air. TLC analysis was conducted using glass-backed thin-layer silica gel chromatography plates (60 $\AA, 250 \mu \mathrm{m}$ thickness, F-254 indicator). Column chromatography was performed using $230-400$ mesh, $60 \AA$ pore diameter silica gels. ${ }^{1} \mathrm{H},{ }^{13} \mathrm{C}$ nuclear magnetic resonance (NMR) spectra were recorded at room temperature using Bruker AV-III-400 and AV-III-800 spectrometers. Chemical shifts ( $\delta$ values) were reported in parts per million and were referenced to the deuterated residual solvent peak. NMR data were reported as $\delta$ value (chemical shift, $J$ value $(\mathrm{Hz})$, integration, where $\mathrm{s}=$ singlet, $\mathrm{d}=$ doublet, $\mathrm{t}=$ triplet, $\mathrm{q}=$ quartet, and brs = broad singlet). Low-resolution mass spectrometry (LRMS) and high-resolution mass spectrometry (HRMS) spectra were recorded at the Purdue University Department of Chemistry Mass Spectrometry Center. High-performance liquid chromatography (HPLC) analysis was carried out an on Agilent 1260 series instrument using a YMC-Pack ODS-A column of $4.6 \mathrm{~mm}$ ID. The purity of all test compounds was determined by HPLC analysis to be $\geq 90 \%$ pure.

5-Chloropyridin-3-yl 1H-indole-4-carboxylate (1). To a stirred solution of commercially available methyl- $1 \mathrm{H}$-indole-4-carboxylate $\mathbf{1 2}$ $(100 \mathrm{mg}, 0.57 \mathrm{mmol})$ in a mixture of ethanol $(3 \mathrm{~mL})$ and water $(3$ $\mathrm{mL}$ ), sodium hydroxide (46 mg, $1.14 \mathrm{mmol}$ ) was added. The resulting reaction mixture was stirred at $85{ }^{\circ} \mathrm{C}$ for $3 \mathrm{~h}$. After this period, the reaction mixture was concentrated under a reduced pressure. The residue was cooled at $0{ }^{\circ} \mathrm{C}$, and the solution was acidified to $\mathrm{pH} 4.5$ using $1 \mathrm{M}$ aqueous $\mathrm{HCl}$. The mixture was extracted with ethyl acetate. The organic layer was dried over anhydrous $\mathrm{Na}_{2} \mathrm{SO}_{4}$ and concentrated under a reduced pressure to give carboxylic acid $(100 \mathrm{mg})$.

To a stirred solution of the above acid $(100 \mathrm{mg}, 0.57 \mathrm{mmol})$ in $\mathrm{CH}_{2} \mathrm{Cl}_{2}$ (3 mL), 5-chloropyridin-3-ol (97 mg, $\left.0.74 \mathrm{mmol}\right)$, EDC (178 $\mathrm{mg}, 0.93 \mathrm{mmol})$, and DMAP $(38 \mathrm{mg}, 0.3 \mathrm{mmol})$ were added. The resulting reaction mixture was stirred at $23{ }^{\circ} \mathrm{C}$ for $12 \mathrm{~h}$. After this period, the reaction mixture was washed with saturated aqueous $\mathrm{NaHCO}_{3}$. The organic layer was dried over anhydrous $\mathrm{Na}_{2} \mathrm{SO}_{4}$ and concentrated under a reduced pressure to give a residue. The residue was purified via silica gel column chromatography ( $40 \%$ ethyl acetate in hexanes) to afford the title ester 1 ( $110 \mathrm{mg}, 71 \%$ in 2 steps $)$ as an amorphous solid. ${ }^{1} \mathrm{H}$ NMR $\left(400 \mathrm{MHz}, \mathrm{CDCl}_{3}\right) \delta 8.73(\mathrm{~s}, 1 \mathrm{H}), 8.56-$ $8.48(\mathrm{~m}, 2 \mathrm{H}), 8.10(\mathrm{~d}, J=7.6 \mathrm{~Hz}, 1 \mathrm{H}), 7.78-7.67(\mathrm{~m}, 2 \mathrm{H}), 7.42(\mathrm{t}, J$ $=2.9 \mathrm{~Hz}, 1 \mathrm{H}), 7.32(\mathrm{t}, J=7.8 \mathrm{~Hz}, 1 \mathrm{H}), 7.27-7.19(\mathrm{~m}, 1 \mathrm{H}) ;{ }^{13} \mathrm{C}$ NMR $\left(100 \mathrm{MHz} \mathrm{CDCl}_{3}\right) \delta 164.9,147.7,145.6,141.6,136.6,131.7$, $129.8,127.9,127.1,124.4,121.2,119.2,117.3,103.7$; LRMS-ESI $(\mathrm{m} /$ $z): 273.0[\mathrm{M}+\mathrm{H}]^{+}$. HRMS (ESI/LTQ) $m / z$. $[\mathrm{M}+\mathrm{H}]^{+}$calcd for $\mathrm{C}_{14} \mathrm{H}_{10} \mathrm{ClN}_{2} \mathrm{O}_{2}$ 273.0425; found 273.0431.

5-Chloropyridin-3-yl indoline-4-carboxylate (2). To a stirred solution of commercially available methyl- $1 \mathrm{H}$-indole-4-carboxylate $\mathbf{1 2}$ $(100 \mathrm{mg}, 0.57 \mathrm{mmol})$ in acetic acid $(3 \mathrm{~mL})$ at $10{ }^{\circ} \mathrm{C}$, sodium cyanoborohydride $(130 \mathrm{mg}, 2.85 \mathrm{mmol})$ was added. The resulting reaction mixture was allowed to warm to $23{ }^{\circ} \mathrm{C}$ and stirred at that temperature for $12 \mathrm{~h}$. After this period, the reaction mixture was concentrated under a reduced pressure. The residue was diluted with aqueous $\mathrm{NaHCO}_{3}$ solution. The mixture was extracted with ethyl acetate. The organic layer was dried over anhydrous $\mathrm{Na}_{2} \mathrm{SO}_{4}$ and concentrated under a reduced pressure to give a crude indoline derivative. The product was purified by silica gel chromatography to give the corresponding indoline derivative $(70 \mathrm{mg}, 69 \%)$.

To a stirred solution of the above indoline methyl ester $(50 \mathrm{mg}$, $0.28 \mathrm{mmol})$ in a mixture of ethanol $(1 \mathrm{~mL})$ and water $(1 \mathrm{~mL})$, sodium hydroxide $(23 \mathrm{mg}, 0.56 \mathrm{mmol})$ was added. The resulting reaction mixture was stirred at $85{ }^{\circ} \mathrm{C}$ for $3 \mathrm{~h}$. After this period, the reaction mixture was concentrated under a reduced pressure. The residue was cooled at $0{ }^{\circ} \mathrm{C}$, and the solution was acidified to $\mathrm{pH} 4.5$ using $1 \mathrm{M}$ aqueous $\mathrm{HCl}$. The mixture was extracted with ethyl acetate. The organic layer was dried over anhydrous $\mathrm{Na}_{2} \mathrm{SO}_{4}$ and concentrated under a reduced pressure to give carboxylic acid $(50 \mathrm{mg})$.

To a stirred solution of indoline carboxylic acid $(120 \mathrm{mg})$ in $\mathrm{CH}_{2} \mathrm{Cl}_{2}$ (3 mL), 5-chloropyridin-3-ol (115 mg, $\left.0.88 \mathrm{mmol}\right)$, EDC $(211 \mathrm{mg}, 1.1 \mathrm{mmol})$, and DMAP $(45 \mathrm{mg}, 0.5 \mathrm{mmol})$ were added. The resulting reaction mixture was stirred at $23{ }^{\circ} \mathrm{C}$ for $12 \mathrm{~h}$. After this period, the reaction mixture was washed with saturated aqueous $\mathrm{NaHCO}_{3}$. The organic layer was dried over anhydrous $\mathrm{Na}_{2} \mathrm{SO}_{4}$ and concentrated under a reduced pressure to give a residue. The residue was purified via silica gel column chromatography ( $40 \%$ ethyl acetate in hexanes) to afford the title ester 2 ( $160 \mathrm{mg}, 55 \%$ over 3 steps) as an 
amorphous solid. ${ }^{1} \mathrm{H}$ NMR (400 MHz, $\mathrm{CDCl}_{3}$ ) $\delta 8.47$ (dd, $J=19.6$, $2.2 \mathrm{~Hz}, 2 \mathrm{H}), 7.66(\mathrm{t}, J=2.2 \mathrm{~Hz}, 1 \mathrm{H}), 7.49(\mathrm{dd}, J=7.9,1.0 \mathrm{~Hz}, 1 \mathrm{H})$, $7.15(\mathrm{t}, J=7.8 \mathrm{~Hz}, 1 \mathrm{H}), 6.87(\mathrm{dd}, J=7.8,1.0 \mathrm{~Hz}, 1 \mathrm{H}), 3.68-3.62(\mathrm{~m}$, $2 \mathrm{H}), 3.45(\mathrm{t}, J=8.5 \mathrm{~Hz}, 2 \mathrm{H}) ;{ }^{13} \mathrm{C} \mathrm{NMR}\left(100 \mathrm{MHz}, \mathrm{CDCl}_{3}\right) \delta 164.3$, $145.7,141.4,129.6,127.7,127.0,124.4,121.2,120.5,117.3,114.3$, 103.7, 46.8, 30.9; LRMS-ESI $(\mathrm{m} / z): 275.0[\mathrm{M}+\mathrm{H}]^{+}$. HRMS (ESI/ LTQ $m / z$. $[\mathrm{M}+\mathrm{H}]^{+}$calcd for $\mathrm{C}_{14} \mathrm{H}_{12} \mathrm{ClN}_{2} \mathrm{O}_{2}$ 275.0582; found 275.0580 .

5-Chloropyridin-3-yl 1H-indole-5-carboxylate (7a). To a stirred solution of methyl- $1 \mathrm{H}$-indole-5-carboxylate $10(92 \mathrm{mg}, 0.52 \mathrm{mmol})$, an aqueous solution of $1 \mathrm{M}$ lithium hydroxide $(2 \mathrm{~mL})$ and THF $(0.5$ $\mathrm{mL}$ ) was added. The resulting reaction mixture was stirred at $23{ }^{\circ} \mathrm{C}$ for $24 \mathrm{~h}$. After this period, the solvent was evaporated under a reduced pressure to give a residue. The residue was cooled at $0{ }^{\circ} \mathrm{C}$, and the solution was acidified to $\mathrm{pH} 3$ using 10\% citric acid. The mixture was extracted with ethyl acetate. The organic layer was dried over anhydrous $\mathrm{Na}_{2} \mathrm{SO}_{4}$ and concentrated under a reduced pressure to give carboxylic acid (5a).

To a stirred solution of the above acid $(69.5 \mathrm{mg}, 0.4 \mathrm{mmol})$ in $\mathrm{CH}_{2} \mathrm{Cl}_{2}$ (3 mL), 5-chloropyridin-3-ol (67 mg, $\left.0.5 \mathrm{mmol}\right)$, EDC (124 $\mathrm{mg}, 0.6 \mathrm{mmol}$ ), and DMAP (53 $\mathrm{mg}, 0.4 \mathrm{mmol}$ ) were added. The resulting reaction mixture was stirred at $23{ }^{\circ} \mathrm{C}$ for $4 \mathrm{~h}$. After this period, the reaction mixture was washed with saturated aqueous $\mathrm{NaHCO}_{3}$. The organic layer was dried over anhydrous $\mathrm{Na}_{2} \mathrm{SO}_{4}$ and concentrated under a reduced pressure to give a residue. The residue was purified via silica gel column chromatography (30\% ethyl acetate in hexanes) to afford the title ester $7 \mathbf{a}$ ( $55 \mathrm{mg}, 47 \%$ in 2 steps) as an amorphous solid. ${ }^{1} \mathrm{H}$ NMR ( $\left.400 \mathrm{MHz}, \mathrm{CDCl}_{3}\right) \delta 9.02(\mathrm{~s}, 1 \mathrm{H}), 8.58$ $(\mathrm{dt}, J=1.6,0.8 \mathrm{~Hz}, 1 \mathrm{H}), 8.50(\mathrm{dd}, J=5.1,2.2 \mathrm{~Hz}, 2 \mathrm{H}), 8.01(\mathrm{dd}, J=$ 8.6, $1.7 \mathrm{~Hz}, 1 \mathrm{H}), 7.71(\mathrm{t}, J=2.2 \mathrm{~Hz}, 1 \mathrm{H}), 7.45(\mathrm{dt}, J=8.6,0.8 \mathrm{~Hz}$, $1 \mathrm{H}), 7.31(\mathrm{dd}, J=3.3,2.3 \mathrm{~Hz}, 1 \mathrm{H}), 6.70(\mathrm{ddd} J=3.1,2.0,0.9 \mathrm{~Hz}$, $1 \mathrm{H}) ;{ }^{13} \mathrm{C} \mathrm{NMR}\left(100 \mathrm{MHz}, \mathrm{CDCl}_{3}\right) \delta 165.4,147.9,145.4,141.5$, 139.1, 131.8, 129.9, 127.6, 126.2, 124.9, 123.7, 119.4, 111.2, 104.1; LRMS-ESI $(m / z): 273.0[\mathrm{M}+\mathrm{H}]^{+}$. HRMS (ESI/LTQ) $\mathrm{m} / z$. $[\mathrm{M}+$ $\mathrm{H}]^{+}$calcd for $\mathrm{C}_{14} \mathrm{H}_{10} \mathrm{ClN}_{2} \mathrm{O}_{2}$ 273.0425; found 273.0433.

5-Chloropyridin-3-yl 1-((3-nitrophenyl)sulfonyl)-1H-indole-5carboxylate (7b). To a stirred solution of indole methyl ester 11 (200 mg, $1.1 \mathrm{mmol}$ ) in THF $(5 \mathrm{~mL})$, sodium hydride $(41 \mathrm{mg}, 60 \%$ suspension in oil, $1.7 \mathrm{mmol}$ ) was added. The resulting reaction mixture was stirred at $0{ }^{\circ} \mathrm{C}$ for $1 \mathrm{~h}$. After this period, 3nitrobenzenesulfonyl chloride $(380 \mathrm{mg}, 1.7 \mathrm{mmol}$ ) was added and the reaction mixture was warmed to $23{ }^{\circ} \mathrm{C}$ and stirred for $9 \mathrm{~h}$. After completion of the reaction, the reaction mixture was cooled to $0{ }^{\circ} \mathrm{C}$ and saturated aqueous $\mathrm{NaCl}$ was added. The reaction mixture was evaporated under a reduced pressure to give a crude residue. The residue was extracted with ethyl acetate and washed with brine. The organic layer was dried over anhydrous $\mathrm{Na}_{2} \mathrm{SO}_{4}$ and concentrated under a reduced pressure. The crude compound was purified via silica gel column chromatography ( $15 \%$ ethyl acetate in hexanes) to afford sulfonamide derivative 10 (170 mg, 41\%). ${ }^{1} \mathrm{H}$ NMR (400 MHz, $\left.\mathrm{CDCl}_{3}\right) \delta 8.72-8.70(\mathrm{~m}, 1 \mathrm{H}), 8.40(\mathrm{ddd}, J=8.2,2.2,1.0 \mathrm{~Hz}, 1 \mathrm{H})$, $8.27(\mathrm{t}, J=1.2 \mathrm{~Hz}, 1 \mathrm{H}), 8.19(\mathrm{ddd}, J=7.9,1.8,1.0 \mathrm{~Hz}, 1 \mathrm{H}), 8.04(\mathrm{~s}$, $2 \mathrm{H}), 7.71-7.66(\mathrm{~m}, 1 \mathrm{H}), 7.63(\mathrm{~d}, J=3.7 \mathrm{~Hz}, 1 \mathrm{H}), 6.80(\mathrm{dd}, J=3.7$, $0.6 \mathrm{~Hz}, 1 \mathrm{H}), 3.92(\mathrm{~s}, 3 \mathrm{H}) ;{ }^{13} \mathrm{C}$ NMR $\left(100 \mathrm{MHz}, \mathrm{CDCl}_{3}\right) \delta 166.7$, $148.2,139.7,137.1,131.9,130.84,130.6,128.4,127.1,126.3,126.1$, 123.9, 121.9, 112.9, 110.8, 52.1; LRMS-ESI $(\mathrm{m} / \mathrm{z}): 391.2[\mathrm{M}+\mathrm{H}]^{+}$.

To a stirred solution of the above ester $(63.6 \mathrm{mg}, 0.18 \mathrm{mmol})$, aqueous $1 \mathrm{M}$ lithium hydroxide $(2 \mathrm{~mL})$ and THF $(0.5 \mathrm{~mL})$ were added. The reaction mixture was stirred at $23{ }^{\circ} \mathrm{C}$ for $9 \mathrm{~h}$. After completion of the reaction, the reaction mixture was concentrated under a reduced pressure. The resulting mixture was cooled at $0{ }^{\circ} \mathrm{C}$ and acidified to $\mathrm{pH} 3$ using $10 \%$ citric acid. The mixture was extracted with ethyl acetate. The organic layer was dried over anhydrous $\mathrm{Na}_{2} \mathrm{SO}_{4}$ and concentrated under a reduced pressure to provide crude acid, which was used for the next reaction without further purification.

To a stirred solution of the above acid $(24 \mathrm{mg}, 0.07 \mathrm{mmol})$ in $\mathrm{CH}_{2} \mathrm{Cl}_{2}(3 \mathrm{~mL})$, 5-chloropyridin-3-ol (11 mg, $\left.0.08 \mathrm{mmol}\right)$, EDC (20 $\mathrm{mg}, 0.10 \mathrm{mmol}$ ), and DMAP (9 $\mathrm{mg}, 0.07 \mathrm{mmol}$ ) were added. The resulting reaction mixture was stirred at $23{ }^{\circ} \mathrm{C}$ for $5 \mathrm{~h}$. After completion of the reaction, the reaction mixture was washed with saturated aqueous $\mathrm{NaHCO}_{3}$. The organic layer was dried over anhydrous $\mathrm{Na}_{2} \mathrm{SO}_{4}$ and concentrated under a reduced pressure. The crude compound was purified via silica gel column chromatography (30\% ethyl acetate in hexanes) to afford the title ester $7 \mathbf{b}(20.4 \mathrm{mg}$, $64 \%$ from 10) as an amorphous solid. ${ }^{1} \mathrm{H}$ NMR $\left(400 \mathrm{MHz}, \mathrm{CDCl}_{3}\right) \delta$ $8.75-8.70(\mathrm{~m}, 1 \mathrm{H}), 8.58(\mathrm{dt}, J=1.6,0.8 \mathrm{~Hz}, 1 \mathrm{H}), 8.50(\mathrm{t}, J=1.9 \mathrm{~Hz}$, $3 \mathrm{H}), 8.02(\mathrm{dd}, J=8.6,1.7 \mathrm{~Hz}, 2 \mathrm{H}), 7.71(\mathrm{t}, J=2.2 \mathrm{~Hz}, 1 \mathrm{H}), 7.48(\mathrm{dt}$, $J=8.6,0.8 \mathrm{~Hz}, 2 \mathrm{H}), 7.33(\mathrm{dd}, J=3.3,2.3 \mathrm{~Hz}, 2 \mathrm{H}), 6.71(\mathrm{ddd}, J=3.1$, 2.0, $1.0 \mathrm{~Hz}, 1 \mathrm{H}) ;{ }^{13} \mathrm{C}$ NMR $\left(100 \mathrm{MHz}, \mathrm{CDCl}_{3}\right) \delta 165.3,147.8,145.5$, $141.6,141.6,138.9,131.7,129.8,127.6,126.1,126.0,125.00,124.9$, $123.8,123.8,119.6,111.1,111.1,104.2,104.2$; LRMS-ESI $(\mathrm{m} / z)$ : $391.2[\mathrm{M}+\mathrm{H}]^{+}$. HRMS (ESI/LTQ) $m / z$. [M ${ }^{+}$-NOS] calcd for $\mathrm{C}_{14} \mathrm{H}_{10} \mathrm{ClN}_{2} \mathrm{O}_{2}$ 273.0425; found 273.0428.

5-Chloropyridin-3-yl 4-methoxy-1H-indole-2-carboxylate (7c). Commercially available 4-methoxy- $1 \mathrm{H}$-indole-2-carboxylic acid (50 $\mathrm{mg}, 0.26 \mathrm{mmol}$ ) was esterified with 5-chloropyridin-3-ol (41 mg, 0.31 $\mathrm{mmol}$ ) by following the procedure for ester $7 \mathrm{a}$ to provide the title ester $7 \mathrm{c}(78 \mathrm{mg}, 99 \%)$ as an amorphous solid.

${ }^{1} \mathrm{H}$ NMR $\left(400 \mathrm{MHz}, \mathrm{CDCl}_{3}\right) \delta 9.19(\mathrm{~s}, 1 \mathrm{H}), 8.51$ (dd, $J=4.9,2.3$ $\mathrm{Hz}, 2 \mathrm{H}), 7.72(\mathrm{t}, J=2.1 \mathrm{~Hz}, 1 \mathrm{H}), 7.62-7.58(\mathrm{~m}, 1 \mathrm{H}), 7.30(\mathrm{t}, J=8.1$ $\mathrm{Hz}, 1 \mathrm{H}), 7.03(\mathrm{~d}, J=8.3 \mathrm{~Hz}, 1 \mathrm{H}), 6.54(\mathrm{~d}, J=7.8 \mathrm{~Hz}, 1 \mathrm{H}), 3.98(\mathrm{~s}$, $3 \mathrm{H}) ;{ }^{13} \mathrm{C} \mathrm{NMR}\left(100 \mathrm{MHz}, \mathrm{CDCl}_{3}\right) \delta 159.2,154.7,147.1,145.9$, 141.26, 138.9, 131.7, 129.4, 127.6, 123.6, 119.0, 109.1, 104.7, 99.9, 55.3; LRMS-ESI $(\mathrm{m} / \mathrm{z}): 303.0[\mathrm{M}+\mathrm{H}]^{+}$. HRMS (ESI/LTQ) $\mathrm{m} / z$. $[\mathrm{M}+\mathrm{H}]^{+}$calcd for $\mathrm{C}_{15} \mathrm{H}_{12} \mathrm{ClN}_{2} \mathrm{O}_{3}$ 303.0531; found 303.0538.

5-Chloropyridin-3-yl 1-allyl-1H-indole-4-carboxylate (7d). 1-Allyl indole-4-carboxylic acid $(40 \mathrm{mg}, 0.20 \mathrm{mmol})$ was esterified with 5chloropyridin-3-ol ( $31 \mathrm{mg}, 0.23 \mathrm{mmol}$ ) by following the procedure for ester 7 a to provide the title ester $7 \mathbf{d}(50 \mathrm{mg}, 80 \%)$ as an amorphous solid. ${ }^{1} \mathrm{H}$ NMR $\left(400 \mathrm{MHz}, \mathrm{CDCl}_{3}\right) \delta 8.52(\mathrm{dd}, J=5.7,2.2 \mathrm{~Hz}, 2 \mathrm{H})$, $8.08(\mathrm{dd}, J=7.6,0.9 \mathrm{~Hz}, 1 \mathrm{H}), 7.74(\mathrm{t}, J=2.2 \mathrm{~Hz}, 1 \mathrm{H}), 7.63(\mathrm{dt}, J=$ 8.2, $0.9 \mathrm{~Hz}, 1 \mathrm{H}), 7.36-7.28(\mathrm{~m}, 2 \mathrm{H}), 7.18(\mathrm{dd}, J=3.1,0.9 \mathrm{~Hz}, 1 \mathrm{H})$, $6.01(\mathrm{ddt}, J=17.1,10.4,5.3 \mathrm{~Hz}, 1 \mathrm{H}), 5.24(\mathrm{dd}, J=10.3,1.3 \mathrm{~Hz}, 1 \mathrm{H})$, $5.07(\mathrm{dd}, J=17.1,1.1 \mathrm{~Hz}, 1 \mathrm{H}), 4.81(\mathrm{~d}, J=5.3 \mathrm{~Hz}, 2 \mathrm{H}) ;{ }^{13} \mathrm{C} \mathrm{NMR}$ $\left(100 \mathrm{MHz}, \mathrm{CDCl}_{3}\right) \delta 164.8,147.6,145.6,141.6,136.83,132.8,131.6$, $130.8,129.7,128.6,124.1,120.7,119.3,117.6,115.7,102.5,48.9$; LRMS-ESI $(m / z): 313.0[\mathrm{M}+\mathrm{H}]^{+}$. HRMS (ESI/LTQ) $m / z$. $[\mathrm{M}+$ $\mathrm{H}]^{+}$calcd for $\mathrm{C}_{17} \mathrm{H}_{14} \mathrm{ClN}_{2} \mathrm{O}_{2}$ 313.0738; found 313.0745.

5-Chloropyridin-3-yl 1,3-diallyl-1 $\mathrm{H}$-indole-4-carboxylate (7e). 1,3-Diallyl indole-4-carboxylic acid $(20 \mathrm{mg}, 0.1 \mathrm{mmol})$ was esterified with 5-chloropyridin-3-ol $(13 \mathrm{mg}, 0.1 \mathrm{mmol})$ by following the procedure for ester $7 \mathrm{a}$ to provide the title ester $7 \mathrm{e}(27 \mathrm{mg}, 96 \%)$ as an amorphous solid. ${ }^{1} \mathrm{H}$ NMR $\left(400 \mathrm{MHz}, \mathrm{CDCl}_{3}\right) \delta 8.51(\mathrm{~s}, 2 \mathrm{H})$, $7.88(\mathrm{dd}, J=7.5,1.0 \mathrm{~Hz}, 1 \mathrm{H}), 7.71(\mathrm{t}, J=2.2 \mathrm{~Hz}, 1 \mathrm{H}), 7.57(\mathrm{dd}, J=$ $8.3,1.0 \mathrm{~Hz}, 1 \mathrm{H}), 7.31-7.24(\mathrm{~m}, 1 \mathrm{H}), 7.10(\mathrm{~d}, J=0.9 \mathrm{~Hz}, 1 \mathrm{H}), 6.12-$ $5.93(\mathrm{~m}, 2 \mathrm{H}), 5.22(\mathrm{dt}, J=10.3,1.4 \mathrm{~Hz}, 1 \mathrm{H}), 5.12-5.01(\mathrm{~m}, 2 \mathrm{H})$, $4.93(\mathrm{dd}, J=17.1,1.9 \mathrm{~Hz}, 1 \mathrm{H}), 4.75(\mathrm{dt}, J=5.3,1.7 \mathrm{~Hz}, 2 \mathrm{H}), 3.70$ $(\mathrm{dq}, J=6.1,1.4 \mathrm{~Hz}, 2 \mathrm{H}) ;{ }^{13} \mathrm{C} \mathrm{NMR}\left(100 \mathrm{MHz}, \mathrm{CDCl}_{3}\right) \delta 165.1$, $145.6,141.6,138.0,137.8,132.8,131.6,129.8,129.6,125.5,123.3$, 123.2, 121.8, 120.3, 117.5, 115.1, 114.8, 113.8, 48.7, 31.6; LRMS-ESI $(m / z): 353.0[\mathrm{M}+\mathrm{H}]^{+}$. HRMS (ESI/LTQ) $m / z .[\mathrm{M}+\mathrm{H}]^{+}$calcd for $\mathrm{C}_{20} \mathrm{H}_{18} \mathrm{ClN}_{2} \mathrm{O}_{2}$ 353.10513; found 353.10442.

5-Chloropyridin-3-yl 3-methyl-1H-indole-4-carboxylate (7f). Commercially available 3-methyl indole-4-carboxylic acid $(20 \mathrm{mg}$, $0.11 \mathrm{mmol})$ was esterified with 5-chloropyridin-3-ol $(18 \mathrm{mg}, 0.14$ $\mathrm{mmol}$ ) by following the procedure for ester $7 \mathrm{a}$ to provide the title ester $7 f$ (30 mg, 92\%) as an amorphous solid. ${ }^{1} \mathrm{H}$ NMR $(400 \mathrm{MHz}$, $\left.\mathrm{CDCl}_{3}\right) \delta 8.51(\mathrm{t}, J=2.3 \mathrm{~Hz}, 2 \mathrm{H}), 8.37(\mathrm{~s}, 1 \mathrm{H}), 7.92(\mathrm{dd}, J=7.5,1.0$ $\mathrm{Hz}, 1 \mathrm{H}), 7.73(\mathrm{t}, J=2.2 \mathrm{~Hz}, 1 \mathrm{H}), 7.61(\mathrm{dd}, J=8.1,1.0 \mathrm{~Hz}, 1 \mathrm{H})$, $7.29-7.23(\mathrm{~m}, 1 \mathrm{H}), 7.16(\mathrm{dt}, J=2.2,1.1 \mathrm{~Hz}, 1 \mathrm{H}), 2.47(\mathrm{~d}, J=1.0 \mathrm{~Hz}$, $3 \mathrm{H}) ;{ }^{13} \mathrm{C} \mathrm{NMR}\left(100 \mathrm{MHz}, \mathrm{CDCl}_{3}\right) \delta 165.2,147.7,145.6,141.5$, $137.8,131.7,129.6,125.9,123.9,121.3,120.9,120.7,116.7,112.6$, 13.7; LRMS-ESI $(m / z): 287.0[\mathrm{M}+\mathrm{H}]^{+}$. HRMS (ESI/LTQ) $m / z$. $[\mathrm{M}+\mathrm{H}]^{+}$calcd for $\mathrm{C}_{15} \mathrm{H}_{12} \mathrm{ClN}_{2} \mathrm{O}_{2}$ 287.05818; found 287.05871.

5-Chloropyridin-3-yl 5-methyl-1H-indole-4-carboxylate (7g). Commercially available 5-methyl indole 4-carboxylic acid $(20 \mathrm{mg}$, $0.11 \mathrm{mmol})$ was esterified with 5-chloropyridin-3-ol $(18 \mathrm{mg}, 0.14$ $\mathrm{mmol}$ ) by following the procedure for ester $7 \mathrm{a}$ to provide the title ester $7 \mathrm{~g}(32 \mathrm{mg}, 98 \%)$ as an amorphous solid. ${ }^{1} \mathrm{H}$ NMR $(400 \mathrm{MHz}$, $\left.\mathrm{CDCl}_{3}\right) \delta 8.53(\mathrm{dd}, J=6.9,2.2 \mathrm{~Hz}, 3 \mathrm{H}), 7.76(\mathrm{t}, J=2.2 \mathrm{~Hz}, 1 \mathrm{H}), 7.52$ 
(dd, $J=8.2,0.9 \mathrm{~Hz}, 1 \mathrm{H}), 7.34(\mathrm{dd}, J=3.2,2.5 \mathrm{~Hz}, 1 \mathrm{H}), 7.15$ (d, $J=$ $8.3 \mathrm{~Hz}, 1 \mathrm{H}), 7.00$ (ddd $J=3.2,2.1,1.0 \mathrm{~Hz}, 1 \mathrm{H}), 2.75(\mathrm{~s}, 3 \mathrm{H}) ;{ }^{13} \mathrm{C}$ NMR $\left(100 \mathrm{MHz}, \mathrm{CDCl}_{3}\right) \delta 165.7,147.5,145.6,141.6,134.9,134.6$, $131.7,129.8,128.0,126.3,125.8,118.5,115.9,103.8,22.0$; LRMS-ESI $(\mathrm{m} / z): 287.0[\mathrm{M}+\mathrm{H}]^{+}$. HRMS (ESI/LTQ) $m / z .[\mathrm{M}+\mathrm{H}]^{+}$calcd for $\mathrm{C}_{15} \mathrm{H}_{12} \mathrm{ClN}_{2} \mathrm{O}_{2}$ 287.05818; found 287.05867 .

5-Chloropyridin-3-yl 6-methyl-1H-indole-4-carboxylate (7h). Commercially available 6-methyl-indole-4-carboxylic acid $(25 \mathrm{mg}$, $0.14 \mathrm{mmol}$ ) was esterified with 5-chloropyridin-3-ol (22 mg, 0.17 $\mathrm{mmol}$ ) by following the procedure for ester $7 \mathbf{a}$ to provide the title ester $7 \mathbf{h}(34 \mathrm{mg}, 83 \%)$ as an amorphous solid. ${ }^{1} \mathrm{H}$ NMR $(400 \mathrm{MHz}$, $\left.\mathrm{CDCl}_{3}\right) \delta 8.52(\mathrm{dd}, J=7.0,2.2 \mathrm{~Hz}, 3 \mathrm{H}), 7.93(\mathrm{dd}, J=1.4,0.7 \mathrm{~Hz}$, $1 \mathrm{H}), 7.74(\mathrm{t}, J=2.2 \mathrm{~Hz}, 1 \mathrm{H}), 7.49(\mathrm{dt}, J=1.7,0.9 \mathrm{~Hz}, 1 \mathrm{H}), 7.34(\mathrm{dd}$, $J=3.2,2.4 \mathrm{~Hz}, 1 \mathrm{H}), 7.14$ (ddd, $J=3.1,2.1,1.0 \mathrm{~Hz}, 1 \mathrm{H}), 2.54(\mathrm{~s}, 3 \mathrm{H})$; ${ }^{13} \mathrm{C}$ NMR $\left(100 \mathrm{MHz}, \mathrm{CDCl}_{3}\right) \delta 164.9,147.7,145.6,141.6,137.1$, $131.7,131.1,129.8,126.4,125.9,125.8,118.7,117.4,103.4,21.3$; LRMS-ESI $(m / z): 287.0[\mathrm{M}+\mathrm{H}]^{+}$. HRMS (ESI/LTQ) $\mathrm{m} / z$. $[\mathrm{M}+$ $\mathrm{H}]^{+}$calcd for $\mathrm{C}_{15} \mathrm{H}_{12} \mathrm{ClN}_{2} \mathrm{O}_{2}$ 287.05818; found 287.05881.

5-Chloropyridin-3-yl 6-fluoro-1H-indole-4-carboxylate (7i). Commercially available 6-fluoro-indole-4-carboxylic acid $(20 \mathrm{mg}$, $0.11 \mathrm{mmol})$ was esterified with 5-chloropyridin-3-ol $(17 \mathrm{mg}, 0.13$ $\mathrm{mmol})$ by following the procedure for ester $7 \mathrm{a}$ to provide the title ester $7 \mathbf{i}(30 \mathrm{mg}, 93 \%)$ as an amorphous solid. ${ }^{1} \mathrm{H}$ NMR $(400 \mathrm{MHz}$, $\left.\mathrm{CDCl}_{3}\right) \delta 8.61-8.50(\mathrm{~m}, 3 \mathrm{H}), 7.83(\mathrm{dd}, J=9.9,2.3 \mathrm{~Hz}, 1 \mathrm{H}), 7.74(\mathrm{t}$, $J=2.2 \mathrm{~Hz}, 1 \mathrm{H}), 7.44-7.39(\mathrm{~m}, 2 \mathrm{H}), 7.19(\mathrm{ddd}, J=3.2,2.1,0.9 \mathrm{~Hz}$, $1 \mathrm{H}) ;{ }^{13} \mathrm{C}$ NMR $\left(100 \mathrm{MHz}, \mathrm{CDCl}_{3}\right) \delta 159.6,157.2,145.8,141.4$, 136.6, 129.7, 127.4, 124.8, 119.7, 112.3, 112.1, 103.9, 103.7, 103.7; LRMS-ESI $(m / z): 291.0[\mathrm{M}+\mathrm{H}]^{+}$. HRMS (ESI/LTQ) $\mathrm{m} / z$. $[\mathrm{M}+$ $\mathrm{H}]^{+}$calcd for $\mathrm{C}_{14} \mathrm{H}_{9} \mathrm{ClFN}_{2} \mathrm{O}_{2}$ 291.03311; found 291.03273.

5-Chloropyridin-3-yl $1 \mathrm{H}$-benzo[d]imidazole-4-carboxylate (7j). Commercially available 1-benzoimidazole-4-carboxylic acid $(50 \mathrm{mg}$, $0.30 \mathrm{mmol}$ ) was esterified with 5-chloropyridin-3-ol $(60 \mathrm{mg}, 0.5$ $\mathrm{mmol}$ ) by following the procedure for ester $7 \mathrm{a}$ to provide the title ester $7 \mathbf{j}(75 \mathrm{mg}, 91 \%)$ as an amorphous solid. ${ }^{1} \mathrm{H}$ NMR $(400 \mathrm{MHz}$, MeOD) $\delta 8.47$ (dd, $J=5.0,2.2 \mathrm{~Hz}, 2 \mathrm{H}), 8.19$ (s, $1 \mathrm{H}), 8.13$ (dd, $J=$ 7.7, $1.0 \mathrm{~Hz}, 1 \mathrm{H}), 8.03(\mathrm{dd}, J=8.0,1.0 \mathrm{~Hz}, 1 \mathrm{H}), 7.79(\mathrm{t}, J=2.2 \mathrm{~Hz}$, $1 \mathrm{H}), 7.43-7.37(\mathrm{~m}, 2 \mathrm{H}) ;{ }^{13} \mathrm{C}$ NMR $(100 \mathrm{MHz}, \mathrm{MeOD}) \delta 163.6$, $145.5,142.8,141.2,132.0,130.2,130.2,126.2,126.1,125.6,122.0$, 121.9, 112.4; LRMS-ESI $(m / z): 274.0 .[\mathrm{M}+\mathrm{H}]^{+}$. HRMS (ESI/LTQ) $m / z .[\mathrm{M}+\mathrm{H}]^{+}$calcd for $\mathrm{C}_{13} \mathrm{H}_{9} \mathrm{ClN}_{3} \mathrm{O}_{2}$ 274.03778; found 274.03732 .

5-Chloropyridin-3-yl 2-methyl-1H-benzo[d]imidazole-4-carboxylate (7k). Commercially available 2-methyl-benzoimidazole-4carboxylic acid (15 $\mathrm{mg}, 0.1 \mathrm{mmol})$ was esterified with 5chloropyridin-3-ol (13 $\mathrm{mg}, 0.1 \mathrm{mmol}$ ) by following the procedure for ester $7 \mathbf{a}$ to provide the title ester $7 \mathbf{k}(20 \mathrm{mg}, 87 \%)$ as an amorphous solid. ${ }^{1} \mathrm{H}$ NMR ( $\left.400 \mathrm{MHz}, \mathrm{CDCl}_{3}\right) \delta 10.41(\mathrm{~s}, 1 \mathrm{H}), 8.52$ $(\mathrm{dd}, J=8.0,2.2 \mathrm{~Hz}, 2 \mathrm{H}), 8.01(\mathrm{dd}, J=27.0,7.8 \mathrm{~Hz}, 2 \mathrm{H}), 7.68(\mathrm{t}, J=$ $2.2 \mathrm{~Hz}, 1 \mathrm{H}), 7.36(\mathrm{t}, J=7.9 \mathrm{~Hz}, 1 \mathrm{H}), 2.69(\mathrm{~s}, 3 \mathrm{H}) ;{ }^{13} \mathrm{C}$ NMR $(100$ $\left.\mathrm{MHz} \mathrm{CDCl}_{3}\right) \delta 164.2,152.7,147.1,146.1,141.3,136.4,135.1,131.8$, $129.5,125.4,124.8,121.8,111.0,14.9$; LRMS-ESI $(\mathrm{m} / z): 288.0[\mathrm{M}+$ $\mathrm{H}]^{+}$. HRMS (ESI/LTQ) $m / z$. $[\mathrm{M}+\mathrm{H}]^{+}$calcd for $\mathrm{C}_{14} \mathrm{H}_{11} \mathrm{ClN}_{3} \mathrm{O}_{2}$ 288.05343; found 288.05302.

5-Chloropyridin-3-yl benzo[d]oxazole-7-carboxylate (7l). Commercially available benzoxazole-7-carboxylic acid $(30.0 \mathrm{mg}, 0.18$ $\mathrm{mmol})$ was esterified with 5-chloropyridin-3-ol $(29 \mathrm{mg}, 0.22 \mathrm{mmol})$ by following the procedure for ester $7 \mathrm{a}$ to provide the title ester $7 \mathbf{l}$ (50 $\mathrm{mg}, 99 \%)$ as an amorphous solid. ${ }^{1} \mathrm{H}$ NMR $\left(400 \mathrm{MHz}, \mathrm{CDCl}_{3}\right) \delta 8.51$ $(\mathrm{d}, J=2.1 \mathrm{~Hz}, 1 \mathrm{H}), 8.49(\mathrm{~d}, J=2.3 \mathrm{~Hz}, 1 \mathrm{H}), 8.43(\mathrm{dd}, J=1.6,0.7 \mathrm{~Hz}$, $1 \mathrm{H}), 8.29(\mathrm{~s}, 1 \mathrm{H}), 8.24(\mathrm{dd}, J=8.4,1.6 \mathrm{~Hz}, 1 \mathrm{H}), 7.92(\mathrm{dd}, J=8.4,0.7$ $\mathrm{Hz}, 1 \mathrm{H}), 7.70(\mathrm{t}, J=2.2 \mathrm{~Hz}, 1 \mathrm{H}) ;{ }^{13} \mathrm{C}$ NMR $\left(100 \mathrm{MHz}, \mathrm{CDCl}_{3}\right) \delta$ ${ }^{13} \mathrm{C}$ NMR $\left(100 \mathrm{MHz}, \mathrm{CDCl}_{3}\right) \delta 163.6,155.4,149.6,147.2,146.1$, 144.8, 141.2, 131.7, 129.4, 126.9, 125.8, 120.8, 113.5; LRMS-ESI $(\mathrm{m} /$ $z$ ): $275.0[\mathrm{M}+\mathrm{H}]^{+}$. HRMS (ESI/LTQ) $\mathrm{m} / z$. $[\mathrm{M}+\mathrm{H}]^{+}$calcd for $\mathrm{C}_{13} \mathrm{H}_{8} \mathrm{ClN}_{2} \mathrm{O}_{3}$ 275.02180; found 275.02129.

5-Chloropyridin-3-yl 3,4-dihydro-2H-benzo[b][1,4]oxazine-8carboxylate $(7 \mathrm{~m})$. Commercially available 3,4-dihydro-benzoxazine8-carboxylic acid $(15 \mathrm{mg}, 0.1 \mathrm{mmol})$ was esterified with 5chloropyridin-3-ol $(13 \mathrm{mg}, 0.1 \mathrm{mmol})$ by following the procedure for ester $7 \mathbf{a}$ to provide the title ester $7 \mathrm{~m}(20 \mathrm{mg}, 83 \%)$ as an amorphous solid. ${ }^{1} \mathrm{H}$ NMR $\left(400 \mathrm{MHz}, \mathrm{CDCl}_{3}\right) \delta 8.45$ (dd, $J=8.9$,
$2.2 \mathrm{~Hz}, 2 \mathrm{H}), 7.68(\mathrm{t}, J=2.2 \mathrm{~Hz}, 1 \mathrm{H}), 7.36(\mathrm{dd}, J=7.1,2.4 \mathrm{~Hz}, 1 \mathrm{H})$, 6.87-6.77 (m, 2H), $4.38(\mathrm{dd}, J=5.1,3.7 \mathrm{~Hz}, 2 \mathrm{H}), 4.00(\mathrm{~s}, 1 \mathrm{H})$, 3.55-3.41 (m, 2H); ${ }^{13} \mathrm{C}$ NMR (100 MHz, $\left.\mathrm{CDCl}_{3}\right) \delta 163.1,147.5$, $145.5,145.3,141.5,134.6,131.5,129.7,120.9,120.4,120.0,116.9$, 65.5, 40.1; LRMS-ESI $(\mathrm{m} / z): 291.0[\mathrm{M}+\mathrm{H}]^{+}$. HRMS (ESI/LTQ) $m / z .[\mathrm{M}+\mathrm{H}]^{+}$calcd for $\mathrm{C}_{14} \mathrm{H}_{12} \mathrm{ClN}_{2} \mathrm{O}_{3}$ 291.05310; found 291.05275 .

$\mathrm{N}$-(5-Chloropyridin-3-yl)-1H-indole-4-carboxamide (9a). Commercially available indole-4-carboxylic acid $(50 \mathrm{mg}, 0.31 \mathrm{mmol})$ was coupled with 5-chloro-3-aminopyridin ( $48 \mathrm{mg}, 0.37 \mathrm{mmol}$ ) by following the procedure of EDC and DMAP for ester $7 \mathbf{a}$ to provide the title amide 9a (40 mg, 47\%) as an amorphous solid. ${ }^{1} \mathrm{H}$ NMR $(400 \mathrm{MHz}, \mathrm{MeOD}) \delta 8.81(\mathrm{~d}, J=2.2 \mathrm{~Hz}, 1 \mathrm{H}), 8.47(\mathrm{t}, J=2.2 \mathrm{~Hz}$, $1 \mathrm{H}), 8.29(\mathrm{~d}, J=2.2 \mathrm{~Hz}, 1 \mathrm{H}), 7.66-7.54(\mathrm{~m}, 2 \mathrm{H}), 7.40(\mathrm{~d}, J=3.2$ $\mathrm{Hz}, 1 \mathrm{H}), 7.23(\mathrm{t}, J=7.8 \mathrm{~Hz}, 1 \mathrm{H}), 6.91(\mathrm{dd}, J=3.2,1.0 \mathrm{~Hz}, 1 \mathrm{H}) ;{ }^{13} \mathrm{C}$ NMR (100 MHz, DMSO) $\delta 167.8,142.5,140.1,137.5,136.9,130.8$, $127.5,126.5,126.3,125.8,120.5,119.6,115.6,102.0$; LRMS-ESI $(\mathrm{m} /$ $z): 272.0[\mathrm{M}+\mathrm{H}]^{+}$. HRMS (ESI/LTQ) $m / z .[\mathrm{M}+\mathrm{H}]^{+}$calcd for $\mathrm{C}_{14} \mathrm{H}_{11} \mathrm{ClN}_{3} \mathrm{O}$ 272.0585; found 272.0591.

$\mathrm{N}$-(3-Chlorophenyl)-1H-indole-4-carboxamide (9b). Indole-4-carboxylic acid (20 mg, $0.12 \mathrm{mmol}$ ) was coupled with 3-chloroaniline $(19 \mathrm{mg}, 0.15 \mathrm{mmol}$ ) by following the procedure of EDC and DMAP for amide $9 \mathbf{a}$ to provide the title amide derivative $9 \mathbf{b}(32 \mathrm{mg}, 95 \%)$ as an amorphous solid. ${ }^{1} \mathrm{H}$ NMR (400 MHz, MeOD) $\delta 7.83(\mathrm{t}, J=2.0$ $\mathrm{Hz}, 1 \mathrm{H}), 7.57-7.48(\mathrm{~m}, 3 \mathrm{H}), 7.31(\mathrm{~d}, J=3.2 \mathrm{~Hz}, 1 \mathrm{H}), 7.25(\mathrm{t}, J=8.1$ $\mathrm{Hz}, 1 \mathrm{H}), 7.17$ (dd, $J=8.1,7.4 \mathrm{~Hz}, 1 \mathrm{H}), 7.07$ (ddd, $J=8.0,2.1,1.0$ $\mathrm{Hz}, 1 \mathrm{H}), 6.86(\mathrm{dd}, J=3.2,1.0 \mathrm{~Hz}, 1 \mathrm{H}) ;{ }^{13} \mathrm{C}$ NMR $(100 \mathrm{MHz}$, MeOD) $\delta 169.1,140.2,136.9,133.9,129.5,129.5,126.0,123.5$, $120.1,120.1,118.8,118.7,118.4,114.4,101.0$; LRMS-ESI $(\mathrm{m} / z)$ : $271.0[\mathrm{M}+\mathrm{H}]^{+}$. HRMS (ESI/LTQ) $m / z$. $[\mathrm{M}+\mathrm{H}]^{+}$calcd for $\mathrm{C}_{15} \mathrm{H}_{12} \mathrm{ClN}_{2} \mathrm{O}$ 271.0633; found 271.0639.

5-Chloro-2-methylpyridin-3-yl $1 \mathrm{H}$-indole-4-carboxylate (9c). Indole-4-carboxylic acid $(50 \mathrm{mg}, 0.31 \mathrm{mmol})$ was esterified with 5chloro-2-methyl-pyridin-3-ol ( $54 \mathrm{mg}, 0.37 \mathrm{mmol})$ by following the procedure for ester $7 \mathrm{a}$ to provide the title ester $9 \mathrm{c}(70.0 \mathrm{mg}, 79 \%)$ as an amorphous solid. ${ }^{1} \mathrm{H}$ NMR $\left(400 \mathrm{MHz}, \mathrm{CDCl}_{3}\right) \delta 8.64(\mathrm{~s}, 1 \mathrm{H})$, $8.42(\mathrm{~d}, J=2.1 \mathrm{~Hz}, 1 \mathrm{H}), 8.12(\mathrm{~d}, J=7.5 \mathrm{~Hz}, 1 \mathrm{H}), 7.72(\mathrm{~d}, J=8.1 \mathrm{~Hz}$, $1 \mathrm{H}), 7.62(\mathrm{~d}, J=2.2 \mathrm{~Hz}, 1 \mathrm{H}), 7.43(\mathrm{t}, J=2.9 \mathrm{~Hz}, 1 \mathrm{H}), 7.33(\mathrm{t}, J=7.8$ $\mathrm{Hz}, 1 \mathrm{H}), 7.24(\mathrm{dd}, J=7.3,4.5 \mathrm{~Hz}, 1 \mathrm{H}), 2.52(\mathrm{~s}, 3 \mathrm{H}) ;{ }^{13} \mathrm{C} \mathrm{NMR}(100$ $\left.\mathrm{MHz} \mathrm{CDCl}_{3}\right) \delta 164.7,150.0,145.8,145.0,136.6,130.0,129.1,127.9$, 127.0, 124.4, 121.2, 119.3, 117.2, 103.8, 19.1; LRMS-ESI $(\mathrm{m} / z)$ : $287.0[\mathrm{M}+\mathrm{H}]^{+}$. HRMS (ESI/LTQ) $m / z$. $[\mathrm{M}+\mathrm{H}]^{+}$calcd for $\mathrm{C}_{15} \mathrm{H}_{12} \mathrm{ClN}_{2} \mathrm{O}_{2}$ 287.05818; found 287.05766.

5-Chloro-4-methylpyridin-3-yl $1 \mathrm{H}$-indole-4-carboxylate (9d). Indole-4-carboxylic acid $(50 \mathrm{mg}, 0.31 \mathrm{mmol})$ was esterified with 5chloro-4-methyl pyridin-3-ol $(45 \mathrm{mg}, 0.31 \mathrm{mmol})$ by following the procedure for ester $7 \mathbf{a}$ to provide the title ester $9 \mathrm{~d}(70 \mathrm{mg}, 79 \%)$ as an amorphous solid. ${ }^{1} \mathrm{H}$ NMR $\left(400 \mathrm{MHz}, \mathrm{CDCl}_{3}\right) \delta 8.71(\mathrm{~s}, 1 \mathrm{H}), 8.50$ $(\mathrm{s}, 1 \mathrm{H}), 8.41(\mathrm{~s}, 1 \mathrm{H}), 8.16-8.10(\mathrm{~m}, 1 \mathrm{H}), 7.72(\mathrm{~d}, J=8.1 \mathrm{~Hz}, 1 \mathrm{H})$, $7.42(\mathrm{t}, J=2.9 \mathrm{~Hz}, 1 \mathrm{H}), 7.33(\mathrm{t}, J=7.8 \mathrm{~Hz}, 1 \mathrm{H}), 7.27-7.20(\mathrm{~m}, 1 \mathrm{H})$, $2.34(\mathrm{~s}, 3 \mathrm{H}) ;{ }^{13} \mathrm{C}$ NMR $\left(100 \mathrm{MHz}, \mathrm{CDCl}_{3}\right) \delta 164.9,146.9,146.1$, 142.0, 138.8, 136.6, 132.8, 127.9, 127.0, 124.4, 121.2, 119.2, 117.2, 103.7, 13.3; LRMS-ESI $(\mathrm{m} / z): 287.0[\mathrm{M}+\mathrm{H}]^{+}$. HRMS (ESI/LTQ) $m / z .[\mathrm{M}+\mathrm{H}]^{+}$calcd for $\mathrm{C}_{15} \mathrm{H}_{12} \mathrm{ClN}_{2} \mathrm{O}_{2} 287.05818$; found 287.05774 .

5-Chloro-6-methylpyridin-3-yl $1 \mathrm{H}$-indole-4-carboxylate (9e). Indole-4-carboxylic acid $(25 \mathrm{mg}, 0.15 \mathrm{mmol})$ was esterified with 5 chloro-6-methyl-pyridin-3-ol $(22 \mathrm{mg}, 0.15 \mathrm{mmol})$ by following the procedure for ester $7 \mathbf{a}$ to provide the title ester $9 \mathrm{e}(32 \mathrm{mg}, 72 \%)$ as an amorphous solid. ${ }^{1} \mathrm{H}$ NMR $\left(400 \mathrm{MHz}, \mathrm{CDCl}_{3}\right) \delta 8.66(\mathrm{~s}, 1 \mathrm{H}), 8.42$ $(\mathrm{d}, J=2.4 \mathrm{~Hz}, 1 \mathrm{H}), 8.09(\mathrm{dd}, J=7.6,0.9 \mathrm{~Hz}, 1 \mathrm{H}), 7.72-7.67(\mathrm{~m}$, $2 \mathrm{H}), 7.41(\mathrm{dd}, J=3.2,2.5 \mathrm{~Hz}, 1 \mathrm{H}), 7.31(\mathrm{t}, J=7.8 \mathrm{~Hz}, 1 \mathrm{H}), 7.23$ (ddd, $J=3.2,2.1,1.0 \mathrm{~Hz}, 1 \mathrm{H}), 2.66(\mathrm{~s}, 3 \mathrm{H}) ;{ }^{13} \mathrm{C}$ NMR $(100 \mathrm{MHz}$, $\left.\mathrm{CDCl}_{3}\right) \delta 165.1,153.1,145.8,140.6,136.5,130.7,130.3,127.8,126.9$, 124.3, 121.1, 119.4, 117.1, 103.7, 22.1; LRMS-ESI $(\mathrm{m} / \mathrm{z}): 287.0[\mathrm{M}+$ $\mathrm{H}]^{+}$. HRMS (ESI/LTQ) $m / z$. $[\mathrm{M}+\mathrm{H}]^{+}$calcd for $\mathrm{C}_{15} \mathrm{H}_{12} \mathrm{ClN}_{2} \mathrm{O}_{2}$ 287.05818; found 287.05768 .

5-Chloro-6-methylpyridin-3-yl $1 \mathrm{H}$-benzo[d]imidazole-4-carboxylate (9f). Commercially available benzoimidazole-4-carboxylic acid $(20 \mathrm{mg}, 0.12 \mathrm{mmol}$ ) was esterified with 5-chloro-6-methyl-pyridin-3ol $(21 \mathrm{mg}, 0.15 \mathrm{mmol})$ by following the procedure for ester $7 \mathrm{a}$ to provide the title ester $9 \mathrm{f}(22 \mathrm{mg}, 62 \%)$ as an amorphous solid. ${ }^{1} \mathrm{H}$ 
NMR (400 MHz, $\left.\mathrm{CDCl}_{3}\right) \delta 8.40(\mathrm{~d}, J=2.4 \mathrm{~Hz}, 1 \mathrm{H}), 8.20(\mathrm{~s}, 1 \mathrm{H})$, 8.17-8.09 (m, 3H), $7.64(\mathrm{~d}, J=2.4 \mathrm{~Hz}, 1 \mathrm{H}), 7.42(\mathrm{t}, J=7.9 \mathrm{~Hz}, 1 \mathrm{H})$, $2.65(\mathrm{~s}, 3 \mathrm{H}) ;{ }^{13} \mathrm{C}$ NMR $\left(100 \mathrm{MHz}, \mathrm{CDCl}_{3}\right) \delta 164.2,153.7,145.2$, $143.5,141.9,140.3,133.6,130.9,129.9,126.6,125.9,122.1,112.1$, 22.1; LRMS-ESI $(m / z): 288.0[\mathrm{M}+\mathrm{H}]^{+}$. HRMS (ESI/LTQ) $m / z$. $[\mathrm{M}+\mathrm{H}]^{+}$calcd for $\mathrm{C}_{14} \mathrm{H}_{11} \mathrm{ClN}_{3} \mathrm{O}_{2}$ 288.0534; found 288.0540.

Purification and Cocrystallization of SARS-CoV-2 and SARSCoV with Inhibitors. SARS-CoV-2 with its authentic $N$ - and $C$ termini was purified according to our recently published methods. ${ }^{25,38}$ Crystals were grown at $4{ }^{\circ} \mathrm{C}$ from $3 \mu \mathrm{L}$ droplets prepared by adding 1 $\mu \mathrm{L}$ of $110 \mu \mathrm{M}$ SARS-CoV-2 3CLpro in $25 \mathrm{mM}$ HEPES pH 7.50, 2.5 $\mathrm{mM} \mathrm{DTT}$, and $1 \%(\mathrm{v} / \mathrm{v})$ dimethylsulfoxide (DMSO)-containing inhibitor stocks to $2 \mu \mathrm{L}$ of reservoir solution. Inhibitors were dissolved in DMSO and added to both crystallization droplets and a cryoprotectant at concentrations of $400 \mu \mathrm{M}$ for compound 2 (GRL01720) and compound 9d (GRL-09120). The reservoir solution for the cocrystal complexes had constant concentrations of $3 \mathrm{mM}$ DTT, $50 \mathrm{mM}$ MES $\mathrm{pH} 6.0$, and 1\% MPD and varying concentrations of PEG 10000 and KCl. The reservoir solution for compound 2 had a PEG 10000 concentration of $22 \%$ and a $\mathrm{KCl}$ concentration of 160 $\mathrm{mM}$. The reservoir solution for compound 9d had a PEG 10000 concentration of $18 \%$ and a $\mathrm{KCl}$ concentration of $120 \mathrm{mM}$. A volume of $3 \mu \mathrm{L}$ of a cryosolution containing an equivalent concentration of an inhibitor prepared in DMSO, $25 \mathrm{mM}$ HEPES $\mathrm{pH}$ 7.50, and 30\% MPD was added to the crystal droplets. Crystals were soaked in the resulting solution for $30 \mathrm{~min}$ and then flash-frozen in liquid nitrogen in $0.05-0.2 \mu \mathrm{m}$ nylon loops. SARS-CoV with its authentic $N$ - and $C$ termini was purified according our previously published methods. ${ }^{48}$

The SARS-CoV 3CLpro-7b (GRL-686) inhibitor complex was crystallized using methods as previously described. ${ }^{49}$ Briefly, purified SARS-CoV 3CLpro was concentrated to $16 \mathrm{mg} / \mathrm{mL}$ in a buffer composed of $20 \mathrm{mM}$ HEPES, pH 7.5, and $5 \mathrm{mM} 2$-mercaptoethanol. The enzyme was incubated on ice with a final concentration of $1 \mathrm{mM}$ inhibitor. A 1:1 enzyme-to-crystallization solution ratio was used, and the crystallization solution consisted of $14.5 \%$ PEG 20000, $50 \mathrm{mM}$ MES, $\mathrm{pH}$ 6.0, $50 \mathrm{mM}$ potassium chloride, and 1\% MPD. Crystallization trials were set up at room temperature using the method of hanging drop vapor diffusion.

Data Collection and Structure Refinement of SARS-CoV-2 3CLpro Inhibitor Complexes. X-ray diffraction data were collected on crystals of enzyme-inhibitor complexes using Life Sciences Collaborative Access Team (LS-CAT) beamlines 21-ID-F and 21-ID$\mathrm{G}$ at the Argonne National Laboratory Advanced Photon Source, Argonne, Illinois, USA. X-ray data were indexed, integrated, and scaled using the HKL2000 software package. ${ }^{50}$ The Phaser-MR module in the PHENIX software suite was used for molecular replacement. ${ }^{51}$ The search model used for molecular replacement was PDB: $6 \mathrm{WNP}^{41}$ with ligands and solvent molecules removed. Inhibitor coordinates and restraints were generated using eLBOW (PHENIX). ${ }^{52}$ Manual modeling building was performed using WinCoot. ${ }^{53}$ Automated structural refinement was performed using the refine module available in PHENIX. Near the end of refinement, TLS restraints were generated and used in the refinement and were left only if they made a significant impact on $R_{\text {free }}$, that is, better than a drop of $1 \%$. Anisotropic B-factors for individual atoms were automatically added by PHENIX if appropriate. The X-ray data collection and refinement statistics for each 3CLpro inhibitor complex are summarized in Table S1 in the Supporting Information.

$I C_{50}$ Value Determination. IC $_{50}$ values were determined for compounds that covalently inhibit SARS-CoV-2 3CLpro using our recently described assay ${ }^{25}$ and data fitting methods that were derived from our previous study on SARS-CoV 3CLpro and inhibition by chloropyridyl esters. ${ }^{34}$ The only difference was that the preincubation time of the enzyme with the compounds was 10 min instead of 20 min. In addition, the Morrison equation was only used to determine the $\mathrm{IC}_{50}$ value when the concentration was below $1 \mu \mathrm{M}$.

\section{ASSOCIATED CONTENT}

\section{SI Supporting Information}

The Supporting Information is available free of charge at https://pubs.acs.org/doi/10.1021/acs.jmedchem.1c01214.

General methods; crystallographic data collection and refinement statistics; cells, viruses, and antiviral activity; immunochemistry assay; full NMR spectroscopy data for all final compounds, and X-ray structural data for inhibitors 2-bound SARS-CoV-2 3CLpro, 7b-bound SARS-CoV 3CLpro, and 9d-bound SARS-CoV-2 3CLpro (PDF)

Molecular formula strings and some data (CSV)

\section{Accession Codes}

The X-ray structures of inhibitors 2-bound SARS-CoV-2 3CLpro, 7b-bound SARS-CoV 3CLpro, and 9d-bound SARSCoV-2 3CLpro are 7RBZ, 7RC1, and 7RC0, respectively. Authors will release the atomic coordinates upon article publication.

\section{AUTHOR INFORMATION}

\section{Corresponding Author}

Arun K. Ghosh - Department of Chemistry and Department of Medicinal Chemistry, Purdue University, West Lafayette, Indiana 47907, United States; 10 orcid.org/0000-00032472-1841; Phone: (765)-494-5323; Email: akghosh@ purdue.edu

\section{Authors}

Jakka Raghavaiah - Department of Chemistry and Department of Medicinal Chemistry, Purdue University, West Lafayette, Indiana 47907, United States

Dana Shahabi - Department of Chemistry and Department of Medicinal Chemistry, Purdue University, West Lafayette, Indiana 47907, United States

Monika Yadav - Department of Chemistry and Department of Medicinal Chemistry, Purdue University, West Lafayette, Indiana 47907, United States

Brandon J. Anson - Department of Biological Sciences, Purdue University, West Lafayette, Indiana 47907, United States

Emma K. Lendy - Department of Biochemistry, Purdue University, West Lafayette, Indiana 47907, United States

Shin-ichiro Hattori - Department of Refractory Viral Infections, National Center for Global Health and Medicine Research Institute, Tokyo 162-8655, Japan

Nobuyo Higashi-Kuwata - Department of Refractory Viral Infections, National Center for Global Health and Medicine Research Institute, Tokyo 162-8655, Japan

Hiroaki Mitsuya - Department of Hematology and Infectious Diseases, Kumamoto University School of Medicine, Kumamoto 860-8556, Japan; Experimental Retrovirology Section, HIV and AIDS Malignancy Branch, National Cancer Institute, Bethesda, Maryland 20892, United States; Department of Refractory Viral Infections, National Center for Global Health and Medicine Research Institute, Tokyo 162-8655, Japan

Andrew D. Mesecar - Department of Biological Sciences and Department of Biochemistry, Purdue University, West Lafayette, Indiana 47907, United States; 다이.org/00000002-1241-2577

Complete contact information is available at: https://pubs.acs.org/10.1021/acs.jmedchem.1c01214 


\section{Notes}

The authors declare no competing financial interest.

\section{ACKNOWLEDGMENTS}

The research was supported in part by grants from the National Institute of Allergy and Infectious Diseases, National Institutes of Health (A.K.G., AI158649 and AI150466, and A.D.M., contract No. HHSN272201700060C). The present work was also supported by a grant for Development of Novel Drugs for Treating COVID-19 from the Intramural Research Program of National Center for Global Health and Medicine (H.M., 19A3001 and S.H., 20A2001D), in part by Japan Agency for Medical Research and Development (AMED) (H.M., 20fk0108257) and by the Intramural Research Program of Center for Cancer Research, National Cancer Institute, National Institutes of Health (H.M.). The authors acknowledge support from the Purdue Center for Cancer Research, NIH grant P30 CA023168 for use of the shared NMR and mass spectrometry facilities. This research used resources of the Advanced Photon Source, a U.S. Department of Energy (DOE) Office of Science User Facility operated for the DOE Office of Science by Argonne National Laboratory under Contract No. DE-AC02-06CH11357. Use of the LS-CAT Sector 21 was supported by the Michigan Economic Development Corporation and the Michigan Technology Tri-Corridor (Grant 085P1000817). The authors would like to thank Anando Ghosh (graphic designer) for his help with the cover art design.

\section{ABBREVIATIONS USED:}

3CLpro, 3-chymotrypsin-like protease; DCC, dicyclohexylcarbodiimide; DMAP, dimethylaminopyridine; EDC, 1-ethyl-3(3-dimethylaminopropyl)carbodiimide; F-actin, filamentous actin; MERS-CoV, Middle East respiratory syndrome coronavirus; MHV coronavirus, mouse hepatitis virus coronavirus; SARS-CoV-2, severe acute respiratory syndrome coronavirus 2 .

\section{REFERENCES}

(1) Li, Q.; Guan, X.; Wu, P.; Wang, X.; Zhou, L.; Tong, Y.; Ren, R.; Leung, K. S. M.; Lau, E. H. Y.; Wong, J. Y.; Xing, X.; Xiang, N.; Wu, Y.; Li, C.; Chen, Q.; Li, D.; Liu, T.; Zhao, J.; Liu, M.; Tu, W.; Chen, C.; Jin, L.; Yang, R.; Wang, Q.; Zhou, S.; Wang, R.; Liu, H.; Luo, Y.; Liu, Y.; Shao, G.; Li, H.; Tao, Z.; Yang, Y.; Deng, Z.; Liu, B.; Ma, Z.; Zhang, Y.; Shi, G.; Lam, T. T. Y.; Wu, J. T.; Gao, G. F.; Cowling, B. J.; Yang, B.; Leung, G. M.; Feng, Z. Early transmission dynamics in Wuhan, China, of novel coronavirus-infected pneumonia. N. Engl. J. Med. 2020, 382, 1199-1207.

(2) Zhou, P.; Yang, X.-L.; Wang, X.-G.; Hu, B.; Zhang, L.; Zhang, W.; Si, H.-R.; Zhu, Y.; Li, B.; Huang, C.-L.; Chen, H.-D.; Chen, J.; Luo, Y.; Guo, H.; Jiang, R.-D.; Liu, M.-Q.; Chen, Y.; Shen, X.-R.; Wang, X.; Zheng, X.-S.; Zhao, K.; Chen, Q.-J.; Deng, F.; Liu, L.-L.; Yan, B.; Zhan, F.-X.; Wang, Y.-Y.; Xiao, G.-F.; Shi, Z.-L. A pneumonia outbreak associated with a new coronavirus of probable bat origin. Nature 2020, 579, 270-273.

(3) Fauci, A. S.; Lane, H. C.; Redfield, R. R. Covid-19 - Navigating the uncharted. New. Engl. J. Med. 2020, 382, 1268-1269.

(4) Mitsuya, H.; Kokudo, N. Sustaining containment of COVID-19: Global sharing for pandemic response. Glob. Health Med. 2020, 2, 53-55.

(5) World Health Organization. Coronavirus disease (COVID-19) Situation Report, https://www.who.int/emergencies/diseases/novelcoronavirus-2019

(6) Scavone, C.; Brusco, S.; Bertini, M.; Sportiello, L.; Rafaniello, C.; Zoccoli, A.; Berrino, L.; Racagni, G.; Rossi, F.; Capuano, A. Current pharmacological treatments for COVID-19: What's next? $\mathrm{Br}$. J. Pharmacol. 2020, 177, 4813-4824.

(7) Wang, M.; Cao, R.; Zhang, L.; Yang, X.; Liu, J.; Xu, M.; Shi, Z.; $\mathrm{Hu}, \mathrm{Z}$; Z Zhong, W.; Xiao, G. Remdesivir and chloroquine effectively inhibit the recently emerged novel coronavirus $(2019-\mathrm{nCoV})$ in vitro. Cell Res. 2020, 30, 269-271.

(8) McCreary, E. K.; Angus, D. C. Efficacy of remdesivir in COVID19. JAMA 2020, 324, 1041-1042.

(9) Spinner, C. D.; Gottlieb, R. L.; Criner, G. J.; Arribas López, J. R.; Cattelan, A. M.; Soriano Viladomiu, A.; Ogbuagu, O.; Malhotra, P.; Mullane, K. M.; Castagna, A.; Chai, L. Y. A.; Roestenberg, M.; Tsang, O. T. Y.; Bernasconi, E.; le Turnier, P.; Chang, S.-C.; SenGupta, D.; Hyland, R. H.; Osinusi, A. O.; Cao, H.; Blair, C.; Wang, H.; Gaggar, A.; Brainard, D. M.; McPhail, M. J.; Bhagani, S.; Ahn, M. Y.; Sanyal, A. J.; Huhn, G.; Marty, F. M.; for the GS-US-540-5774 Investigators. Effect of remdesivir vs standard care on clinical status at 11 days in patients with moderate COVID-19. A randomized clinical trial. JAMA 2020, 324, 1048-1057.

(10) Kaur, S. P.; Gupta, V. COVID-19 vaccine: A comprehensive status report. Virus Res. 2020, 288, No. 198114.

(11) on behalf of the COVID-19 Commission of Accademia Nazionale dei Lincei, Rome; Forni, G.; Mantovani, A. COVID-19 vaccines: Where we stand and challenges ahead. Cell Death Differ. 2021, 28, 626-639.

(12) Spellberg, B.; Nielsen, T. B.; Casadevall, A. Antibodies, immunity, and COVID-19. JAMA Intern. Med. 2021, 181, 460-462.

(13) Poland, G. A.; Ovsyannikova, I. G.; Kennedy, R. B. SARS-CoV2 immunity: Review and applications to phase 3 vaccine candidates. Lancet 2020, 396, 1595-1606.

(14) Wan, Y.; Shang, J.; Graham, R.; Baric, R. S.; Li, F. Receptor recognition by the novel coronavirus from Wuhan: An analysis based on decade-long structural studies of SARS coronavirus. J. Virol. 2020, 94, e00127-e00120.

(15) Tse, L. V.; Meganck, R. M.; Graham, R. L.; Baric, R. S. The current and future state of vaccines, antivirals and gene therapies against emerging coronaviruses. Front. Microbiol. 2020, 11, 495-504.

(16) Kaul, D. An overview of coronaviruses including the SARS-2 coronavirus - Molecular biology, epidemiology and clinical implications. Curr. Med. Res. Pract. 2020, 10, 54-64.

(17) Fehr, A. R.; Perlman, S. Coronaviruses: An overview of their replication and pathogenesis. In Coronaviruses. Methods in Molecular Biology; Maier, H.; Bickerton, E.; Britton, P.. Humana Press: New York, NY, 2015; vol 1282.

(18) Coronaviridae Study Group of the International Committee on Taxonomy of Viruses. The species severe acute respiratory syndromerelated coronavirus: classifying $2019-\mathrm{nCoV}$ and naming it SARS-CoV2. Nat. Microbiol. 2020, 5, 536-544.

(19) Forni, D.; Cagliani, R.; Clerici, M.; Sironi, M. Molecular evolution of human coronavirus genomes. Trends Microbiol. 2017, 25, $35-48$.

(20) Ghosh, A. K.; Xi, K.; Johnson, M. E.; Baker, S. C.; Mesecar, A. D. Progress in anti-SARS coronavirus chemistry, biology and chemotherapy. Annu. Rep. Med. Chem. 2007, 41, 183-196.

(21) Pillaiyar, T.; Manickam, M.; Namasivayam, V.; Hayashi, Y.; Jung, S.-H. An overview of severe acute respiratory syndromecoronavirus (SARS-CoV) 3CL protease inhibitors: Peptidomimetics and small molecule chemotherapy. J. Med. Chem. 2016, 59, 65956628.

(22) Pillaiyar, T.; Meenakshisundaram, S.; Manickam, M. Recent discovery and development of inhibitors targeting coronaviruses. Drug Discovery Today 2020, 25, 668-688.

(23) Ghosh, A. K.; Brindisi, M.; Shahabi, D.; Chapman, M. E.; Mesecar, A. D. Drug development and medicinal chemistry efforts toward SARS-coronavirus and Covid-19 therapeutics. ChemMedChem 2020, 15, 907-932.

(24) Roe, M. K.; Junod, N. A.; Young, A. R.; Beachboard, D. C.; Stobart, C. C. Targeting novel structural and functional features of coronavirus protease nsp5 (3CLpro, Mpro) in the age of COVID-19. J. Gen. Virol. 2021, 102, No. 001558. 
(25) Han, S. H.; Goins, C. M.; Arya, T.; Shin, W.-J.; Maw, J.; Hooper, A.; Sonawane, D. P.; Porter, M. R.; Bannister, B. E.; Crouch, R. D.; Lindsey, A. A.; Lakatos, G.; Martinez, S. R.; Alvarado, J.; Akers, W. S.; Wang, N. S.; Jung, J. U.; Macdonald, J. D.; Stauffer, S. R. Structure-based optimization of ML300-derived, noncovalent inhibitors targeting the severe acute respiratory syndrome coronavirus $3 \mathrm{CL}$ protease (SARS-CoV-2 3CL ${ }^{\text {pro }}$ ). J. Med. Chem. 2021, DOI: 10.1021/ acs.jmedchem.1c00598.

(26) Hattori, S.-I.; Higashi-Kuwata, N.; Hayashi, H.; Allu, S. R.; Raghavaiah, J.; Bulut, H.; Das, D.; Anson, B. J.; Lendy, E. K.; Takamatsu, Y.; Takamune, N.; Kishimoto, N.; Murayama, K.; Hasegawa, K.; Li, M.; Davis, D. A.; Kodama, E. N.; Yarchoan, R.; Wlodawer, A.; Misumi, S.; Mesecar, A. D.; Ghosh, A. K.; Mitsuya, H. A small molecule compound with an indole moiety inhibits the main protease of SARS-CoV-2 and blocks virus replication. Nat. Commun. 2021, 12, 668 .

(27) Qiao, J.; Li, Y.-S.; Zeng, R.; Liu, F.-L.; Luo, R.-H.; Huang, C.; Wang, Y. F.; Zhang, J.; Quan, B.; Shen, C.; Mao, X.; Liu, X.; Sun, W.; Yang, W.; Ni, X.; Wang, K.; Xu, L.; Duan, Z.-L.; Zou, Q.-C.; Zhang, H.-L.; Qu, W.; Long, Y.-H.-P.; Li, M.-H.; Yang, R.-C.; Liu, X.; You, J.; Zhou, Y.; Yao, R.; Li, W.-P.; Liu, J.-M.; Chen, P.; Liu, Y.; Lin, G.-F.; Yang, X.; Zou, J.; Li, L.; Hu, Y.; Lu, G.-W.; Li, W.-M.; Wei, Y.-Q.; Zheng, Y.-T.; Lei, J.; Yang, S. SARS-CoV-2 $\mathrm{M}^{\text {pro }}$ inhibitors with antiviral activity in a transgenic mouse model. Science 2021, 371, 1374-1378.

(28) Halford, B. Pfizer unveils its oral SARS-CoV-2 inhibitor. Chem. Eng. News 2021, 99, 7-7.

(29) Hattori, S.-I.; Higshi-Kuwata, N.; Raghavaiah, J.; Das, D.; Bulut, H.; Davis, D. A.; Takamatsu, Y.; Matsuda, K.; Takamune, N.; Kishimoto, N.; Okamura, T.; Misumi, S.; Yarchoan, R.; Maeda, K.; Ghosh, A. K.; Mitsuya, H. GRL-0920, an indole chloropyridinyl ester, completely blocks SARS-CoV-2 infection. MBio 2020, 11, e01833e01820.

(30) Ghosh, A. K.; Xi, K.; Ratia, K.; Santarsiero, B. D.; Fu, W.; Harcourt, B. H.; Rota, P. A.; Baker, S. C.; Johnson, M. E.; Mesecar, A. $D$. Design and synthesis of peptidomimetic severe acute respiratory syndrome chymotrypsin-like protease inhibitors. J. Med. Chem. 2005, 48, 6767-6771.

(31) Ghosh, A. K.; Xi, K.; Grum-Tokars, V.; Xu, X.; Ratia, K.; Fu, W.; Houser, K. V.; Baker, S. C.; Johnson, M. E.; Mesecar, A. D. Structure-based design, synthesis, and biological evaluation of peptidomimetic SARS-CoV 3CLpro inhibitors. Bioorg. Med. Chem. Lett. 2007, 17, 5876-5880.

(32) Ratia, K.; Pegan, S.; Takayama, J.; Sleeman, K.; Coughlin, M.; Baliji, S.; Chaudhuri, R.; Fu, W.; Prabhakar, B. S.; Johnson, M. E.; Baker, S. C.; Ghosh, A. K.; Mesecar, A. D. A noncovalent class of papain-like protease/deubiquitinase inhibitors blocks SARS virus replication. Proc. Natl. Acad. Sci. U. S. A. 2008, 105, 16119-16124.

(33) Pokrovskaya, V.; Belakhov, V.; Hainrichson, M.; Yaron, S.; Baasov, T. Design, Synthesis, and Evaluation of Novel Fluoroquinolone-Aminoglycoside Hybrid Antibiotics. J. Med. Chem. 2009, 52, 2243-2254.

(34) Ghosh, A. K.; Takayama, J.; Rao, K. V.; Ratia, K.; Chaudhuri, R.; Mulhearn, D. C.; Lee, H.; Nichols, D. B.; Baliji, S.; Baker, S. C.; Johnson, M. E.; Mesecar, A. D. Severe acute respiratory syndrome coronavirus papain-like novel protease inhibitors: Design, synthesis, protein-ligand $\mathrm{x}$-ray structure and biological evaluation. J. Med. Chem. 2010, 53, 4968-4979.

(35) Ghosh, A. K.; Gong, G.; Grum-Tokars, V.; Mulhearn, D. C.; Baker, S. C.; Coughlin, M.; Prabhakar, B. S.; Sleeman, K.; Johnson, M. E.; Mesecar, A. D. Design, synthesis and antiviral efficacy of a series of potent chloropyridyl ester-derived SARS-CoV 3CLpro inhibitors. Bioorg. Med. Chem. Lett. 2008, 18, 5684-5688.

(36) Wu, C. Y.; King, K. Y.; Kuo, C. J.; Fang, J. M.; Wu, Y. T.; Ho, M. Y.; Liao, C. L.; Shie, J. J.; Liang, P. H.; Wong, C. H. Stable benzotriazole esters as mechanism-based inactivators of the severe acute respiratory syndrome 3CL protease. Chem. Biol. 2006, 13, 261268.
(37) Blanchard, J. E.; Elowe, N. H.; Huitema, C.; Fortin, P. D.; Cechetto, J. D.; Eltis, L. D.; Brown, E. D. High-throughput screening identifies inhibitors of the SARS coronavirus main proteinase. Chem. Biol. 2004, 11, 1445-1453.

(38) Zhang, J.; Pettersson, H. I.; Huitema, C.; Niu, C.; Yin, J.; James, M. N.; Eltis, L. D.; Vederas, J. C. Design, synthesis, and evaluation of inhibitors for severe acute respiratory syndrome 3C-like protease based on phthalhydrazide ketones or heteroaromatic esters. J. Med. Chem. 2007, 50, 1850-1864.

(39) Yao, C.-H.; Song, J.-S.; Chen, C.-T.; Yeh, T.-K.; Hsieh, T.-C.; Wu, S.-H.; Huang, C.-Y.; Huang, Y.-L.; Wang, M.-H.; Liu, Y.-W.; Tsai, C.-H.; Kumar, C. R.; Lee, J.-C. Synthesis and biological evaluation of novel C-indolylxylosides as sodium-dependent glucose co-transporter 2 inhibitors. Eur. J. Med. Chem. 2012, 55, 32-38.

(40) Cardillo, B.; Casnati, G.; Pochini, A.; Ricca, A. Alkylation of indole sodium salt as ambifunctional nucleophilic system. Tetrahedron 1967, 23, 3771-3783.

(41) Anson, B. J.; Chapman, M. E.; Lendy, E. K.; Pshenychnyi, S.; D’Aquila, R. T.; Satchell, K. J. F.; Mesecar, A. D., Broad-spectrum inhibition of coronavirus main and papain-like proteases by HCV drugs. Res. Square, 2020, preprint. DOI: 10.21203/rs.3.rs-26344/v1. (42) Grum-Tokars, V.; Ratia, K.; Begaye, A.; Baker, S. C.; Mesecar, A. D. Evaluating the $3 \mathrm{C}$-like protease activity of SARS-Coronavirus: recommendations for standardized assays for drug discovery. Virus Res. 2008, 133, 63-73.

(43) Hoffman, R. L.; Kania, R. S.; Brothers, M. A.; Davies, J. F.; Ferre, R. A.; Gajiwala, K. S.; He, M.; Hogan, R. J.; Kozminski, K.; Li, L. Y.; Lockner, J. W.; Lou, J.; Marra, M. T.; Mitchell, L. J., Jr.; Murray, B. W.; Nieman, J. A.; Noell, S.; Planken, S. P.; Rowe, T.; Ryan, K.; Smith, G. J., III; Solowiej, J. E.; Steppan, C. M.; Taggart, B. Discovery of ketone-based covalent inhibitors of coronavirus 3CL proteases for the potential therapeutic treatment of COVID-19. J. Med. Chem. 2020, 63, 12725-12747.

(44) de Vries, M.; Mohamed, A. S.; Prescott, R. A.; Valero-Jimenez, A. M.; Desvignes, L.; O’Connor, R.; Steppan, C.; Devlin, J. C.; Ivanova, E.; Herrera, A.; Schinlever, A.; Loose, P.; Ruggles, K.; Koralov, S. B.; Anderson, A. S.; Binder, J.; Dittmann, M. A comparative analysis of SARS-CoV-2 antivirals characterizes 3CLpro inhibitor PF-00835231 as a potential new treatment for COVID-19. J. Virol. 2021, 95, e01819-e01820.

(45) Mesecar, A. D.; Stoddard, B. L.; Koshland de Jr. Orbital steering in the catalytic power of enzymes: Small structural changes with large catalytic consequences. Science 1997, 277, 202-206.

(46) Maeda, K.; Higashi-Kuwata, N.; Kinoshita, N.; Kutsuna, S.; Tsuchiya, K.; Hattori, S.-I.; Matsuda, K.; Takamatsu, Y.; Gatanaga, H.; Oka, S.; Sugiyama, H.; Ohmagari, N.; Mitsuya, H. Neutralization of SARS-CoV-2 with IgG from COVID-19-convalescent plasma. Sci. Rep. 2021, 11, 5563.

(47) Verschueren, K. H. G.; Pumpor, K.; Anemüller, S.; Chen, S.; Mesters, J. R.; Hilgenfeld, R. A structural view of the inactivation of the SARS coronavirus main proteinase by benzotriazole esters. Chem. Biol. 2008, 15, 597-606.

(48) Deng, X.; StJohn, S. E.; Osswald, H. L.; O’Brien, A.; Banach, B. S.; Sleeman, K.; Ghosh, A. K.; Mesecar, A. D.; Baker, S. C. Coronaviruses resistant to a $3 \mathrm{C}$-like protease inhibitor are attenuated for replication and pathogenesis, revealing a low genetic barrier but high fitness cost of resistance. J. Virol. 2014, 88, 11886-11898.

(49) Jacobs, J.; Grum-Tokars, V.; Zhou, Y.; Turlington, M.; Saldanha, S. A.; Chase, P.; Eggler, A.; Dawson, E. S.; Baez-Santos, Y. M.; Tomar, S.; Mielech, A. M.; Baker, S. C.; Lindsley, C. W.; Hodder, P.; Mesecar, A.; Stauffer, S. R. Discovery, synthesis, and structure-based optimization of a series of $N$-(tert-butyl)-2-( $N$ arylamido)-2-(pyridin-3-yl) acetamides (ML188) as potent noncovalent small molecule inhibitors of the severe acute respiratory syndrome coronavirus (SARS-CoV) 3CL protease. J. Med. Chem. 2013, 56, 534-546.

(50) Otwinowski, Z.; Minor, W. Processing of x-ray diffraction data collected in oscillation mode. Methods Enzymol. 1997, 276, 307-326. 
(51) Adams, P. D.; Afonine, P. V.; Bunkóczi, G.; Chen, V. B.; Davis, I. W.; Echols, N.; Headd, J. J.; Hung, L.-W.; Kapral, G. J.; GrosseKunstleve, R. W.; McCoy, A. J.; Moriarty, N. W.; Oeffner, R.; Read, R. J.; Richardson, D. C.; Richardson, J. S.; Terwilliger, T. C.; Zwart, P. H. PHENIX: A comprehensive python-based system for macromolecular structure solution. Acta. Crystallogr. D Biol. Crystallogr. 2010, 66, 213-221.

(52) Moriarty, N. W.; Grosse-Kunstleve, R. W.; Adams, P. D. electronic ligand builder and optimization workbench (eLBOW): A tool for ligand coordinate and restraint generation. Acta. Crystallogr. D Biol. Crystallogr. 2009, 65, 1074-1080.

(53) Emsley, P.; Lohkamp, B.; Scott, W. G.; Cowtan, K. Features and development of coot. Acta. Crystallogr. D. Biol. Crystallogr. 2010, $66,486-501$. 